\title{
Albert Moll's Ambivalence about Homosexuality and His Marginalization as a Sexual Pioneer
}

Citation for published version (APA):

Oosterhuis, H. (2019). Albert Moll's Ambivalence about Homosexuality and His Marginalization as a Sexual Pioneer. Journal of the History of Sexuality, 28(1), 1-43. https://doi.org/10.7560/JHS28101

Document status and date:

Published: 01/01/2019

DOI:

10.7560/JHS28101

Document Version:

Publisher's PDF, also known as Version of record

Document license:
Taverne

\section{Please check the document version of this publication:}

- A submitted manuscript is the version of the article upon submission and before peer-review. There can be important differences between the submitted version and the official published version of record.

People interested in the research are advised to contact the author for the final version of the publication, or visit the DOI to the publisher's website.

- The final author version and the galley proof are versions of the publication after peer review.

- The final published version features the final layout of the paper including the volume, issue and page numbers.

Link to publication

\footnotetext{
General rights rights.

- You may freely distribute the URL identifying the publication in the public portal. please follow below link for the End User Agreement:

www.umlib.nl/taverne-license

Take down policy

If you believe that this document breaches copyright please contact us at:

repository@maastrichtuniversity.nl

providing details and we will investigate your claim.
}

Copyright and moral rights for the publications made accessible in the public portal are retained by the authors and/or other copyright owners and it is a condition of accessing publications that users recognise and abide by the legal requirements associated with these

- Users may download and print one copy of any publication from the public portal for the purpose of private study or research.

- You may not further distribute the material or use it for any profit-making activity or commercial gain

If the publication is distributed under the terms of Article $25 \mathrm{fa}$ of the Dutch Copyright Act, indicated by the "Taverne" license above, 


\section{PROJECT MUSE*}

Albert Moll's Ambivalence about Homosexuality and His Marginalization as a Sexual Pioneer

Harry Oosterhuis

Journal of the History of Sexuality, Volume 28, Number 1, January 2019, pp. 1-43 (Article)

Published by University of Texas Press

$\Rightarrow$ For additional information about this article https://muse.jhu.edu/article/716124 


\title{
Albert Moll's Ambivalence about Homosexuality and His Marginalization as a Sexual Pioneer
}

\author{
HARRY OOSTERHUIS \\ Maastricht University
}

The names of pioneers such as Richard von Krafft-Ebing, Sigmund Freud, Havelock Ellis, and Magnus Hirschfeld, who carved out sexology as a new scientific field, are well-known. However, others whose thought was crucial to the field have largely been neglected. The German neurologist Albert Moll (1862-1939) is certainly one of them. His name, to be sure, appears frequently in historical works about sexuality, but his life and work warrant more attention than they have received so far. If in the early twentieth century Moll was one of the best-known experts in sexology in Central Europe, his fame had waned by the time he died on 23 September 1939, on the very same day as Freud. His reputation was eclipsed by the widespread adoption of Freud's psychoanalytic theory and by Hirschfeld's prominence as an epoch-making protagonist of sexual reform and the homosexual rights movement. Unlike Freud and Hirschfeld, with whom Moll was engaged in bitter conflicts, he did not establish a school or activist movement. Nor did he ever hold a university position, meaning that he lacked the opportunity to have students and followers who might have taken up and popularized his work.

By the 1890s, before Freud, Ellis, and Hirschfeld became influential, Moll had already elaborated the most comprehensive and sophisticated sexual theory to date. But his innovative and ingenious reflections on sexuality, including biological as well as psychological and sociocultural factors, have received far less attention from historians of sexuality and in lesbian and gay studies than those of his contemporaries. When his contributions to sexology are mentioned at all, it is often only in passing and in a one-sided and judgmental way. His antagonism toward the putatively enlightened and progressive views of Freud and Hirschfeld have led many commentators to highlight his political conservatism and regressive views of homosexuality and to therefore overlook his more innovative thinking about sexuality. ${ }^{1}$

I am indebted to Gert Hekma, Annette Timm, and two anonymous reviewers for their useful comments on an earlier draft of this article.

${ }^{1}$ See, for example, Manfred Herzer, Magnus Hirschfeld: Leben und Werk eines jüdischen, schwulen und sozialistischen Sexologen (Frankfurt: Campus Verlag, 1992), 8, 127-29; Vern L. 
Moll's life and works are full of contradictions, and they reflect some of the ambiguities in the development of the modern science and politics of sexuality.

In this article I highlight how Moll's understanding and changing judgment of homosexuality vacillated between three explanatory frameworks: gender inversion, sexual object choice, and age disparity. Whereas the first one had been typical of new biomedical theories since the late nineteenth century, the second instead pointed to the future, and the third drew on older patterns of thinking about homosexual behavior. Moll's changing and partly contradictory views of homosexuality were not only intertwined with his ingenious explanations of sexuality in general but also related to the variety of same-sex practices that he witnessed, his professional interests as a private psychotherapist, his antagonistic position vis-à-vis Hirschfeld and Freud, and his mixed feelings about homosexual emancipation and the impact of sexology on society. I will demonstrate how all of these factors throw light on the ambiguities of sexual modernity and may also explain Moll's eventual marginalization in sexology and sexual history, even though his work now actually seems less outdated than that of some of his colleagues. $^{2}$

\section{Moll's Controversial Reputation}

From around 1890, Moll ran a thriving private practice in West Berlin for nervous and mental disorders. He belonged to a group of doctors who

Bullough, Science in the Bedroom: A History of Sex Research (New York: Basic Books, 1994), 59, 74-75; Andreas Pretzel, "Sexualreform im Spannungsfeld weltanschaulicher Veraussetzungen und sozialpolitischer Auseinandersetzungen," in Verqueere Wissenschaft? Zum Verhältnis von Sexualwissenschaft und Sexualreformbewegung in Geschichte und Gegenwart, ed. Ursula Ferdinand, Andreas Pretzel, and Andreas Seeck (Münster: Lit Verlag, 1998), 229-42, see 241; Gunter Schmidt, "Helfer und Verfolger: Die Rolle von Wissenschaft und Medizin in der Homosexuellenfrage," in Durch Wissenschaft zur Gerechtigkeit? Textsammlung zur kritischen Rezeption des Schaffens von Magnus Hirschfeld, ed. Andreas Seeck (Münster: Lit Verlag, 2003), 39-55, 41-42; Edward Ross Dickinson, Sex, Freedom, and Power in Imperial Germany, 1880-1914 (Cambridge: Cambridge University Press, 2014), 250; Laurie Marhoefer, Sex and the Weimar Republic: German Homosexual Emancipation and the Rise of the Nazis (Toronto: University of Toronto Press, 2015), 96, 128; Ralph M. Leck, Vita Sexualis: Karl Ulrichs and the Origins of Sexual Science (Urbana: University of Illinois Press, 2016); and Kirsten Leng, Sexual Politics and Feminist Science: Women Sexologists in Germany 1900-1933 (Ithaca, NY: Cornell University Press and Cornell University Library, 2018), 60. For examples of more elaborate and balanced accounts of Moll's life and work, see the proceedings of a 2009 conference published in Medical History 56, no. 2 (2012); and Volkmar Sigusch, "Albert Moll," in Personenlexikon der Sexualforschung, ed. Volkmar Sigusch and Günter Grau (Frankfurt am Main: Campus Verlag, 2009), 511-21.

${ }^{2}$ Manfred Herzer claims that early twentieth-century sexology, including Moll's work, is completely obsolete, particularly because it was dominated by biological reductionism. Such a judgment ignores the open character and versatility of sexual science, which included psychological and cultural perspectives. See Herzer, Magnus Hirschfeld, 8. 
from the mid-1880s on began to apply hypnotism and other psychological methods to the treatment of psychosomatic complaints, including addictions, sexual problems, and "perversions," in particular, homosexuality. ${ }^{3}$ In addition, he regularly served in court as an expert witness on the mental state and legal responsibility of defendants, in particular, sexual offenders. He was an elected member of various medical associations and a consultant in matters of public health and military medicine, roles that led to direct communication with government and police officials. His public visibility was boosted through his regular contributions to public debates, his role in sensational trials, and his association with intellectual and aristocratic circles.

Within little more than ten years, Moll published pioneering and wellreceived books about hypnosis, sexuality, and medical ethics, establishing his eminence in these fields. ${ }^{4}$ His scholarly publications qualified him for a professorship, but he would never hold an academic chair. It is unlikely that his Jewish background, which he shared with some other German and Austrian pioneers of sexology (Iwan Bloch, Albert Eulenburg, Freud, Hirschfeld, and Max Marcuse), stood in the way: he converted to Protestantism, probably with an eye to his career prospects, and he was a fully integrated member of the secularized educated middle class (Bildungsbürgertum). However, his reputation in the not fully respectable field of sexology and his criticism of the exclusively natural-scientific approach in German medicine may have worked against him: in Moll's view, physicians lacked psychological understanding. Moreover, he antagonized the academic world in Berlin with fierce attacks on medical colleagues. After having annoyed psychiatrists in private mental institutions with accusations that they allowed compulsory admissions that were dubious and that they kept recovered patients hospitalized longer than necessary in order to make extra profits, in the late 1890s Moll vented his outrage about the way patients in university hospitals, particularly in the field of bacteriology and research into syphilis, were being subjected to experimentation without informed consent. In his view this was a serious violation of patients' fundamental right of self-determination. ${ }^{5}$ Moll's reputation as a troublemaker was also heightened when he criticized the so-called patient trade-the lucrative practice of paying middlemen to refer

\footnotetext{
${ }^{3}$ Andreas-Holger Maehle, "The Powers of Suggestion: Albert Moll and the Debate on Hypnosis," History of Psychiatry 25, no. 1 (2014): 3-19.

${ }^{4}$ His main works include Albert Moll, Der Hypnotismus (Berlin: Fischer's medicinische Buchhandlung, H. Kornfeld, 1889); Moll, Die Conträre Sexualempfindung: Mit Benutzung amtlichen Materials (Berlin: Fischer's medicinische Buchhandlung, H. Kornfeld, 1891); Moll, Untersuchungen über die Libido sexualis (Berlin: Fischer's medicinische Buchhandlung, H. Kornfeld, 1898) (the 1898 edition, which has two parts and to which I refer in this article, was the second one after the first edition of 1897, which included only part 1); Moll, Ärztliche Ethik: Die Pflichten des Arztes in allen Beziehungen seiner Thätigkeit (Stuttgart: Ferdinand Enke, 1902).

${ }^{5}$ Albert Moll, "Privatirrenanstalten," Die Zukunft 7 (1894): 550-58; Moll, "Reform der Privatirrenanstalten," Die Zukunft 11 (1895): 65-71; Moll, "Versuche am lebenden Menschen," Die Zukunft 29 (1899): 213-18.
} 
foreign patients to specialists in hospitals and university clinics. The subsequent libel trial entailed wide publicity for his allegations, which blemished the prestige of German medicine. Moll's accusations led government officials, probably at the instigation of leading university doctors, to request a police report about him. The report, completed in 1901, characterized Moll as a respectable physician but noted areas of concern: his specialization in hypnotism and sexual perversion; his exceptional and radical positions; his attacks on asylum doctors; the prostitutes among his patients; certain rumors about mysterious things going on in his apartment, including the fact that private detectives had been seen there; and his membership in the German Progressive Party. ${ }^{6}$

Moll belonged to the Berlin medical establishment and was anxious about his own professional reputation, yet he expressed himself in public with little regard for the possible harmful consequences for his position. As a critic and debater, he was relentless, not shying away from ad hominem attacks on opponents. His confrontational behavior often alienated him from others, including allies and close friends. ${ }^{7}$ Hardly anything is known about Moll's private life as a life-long bachelor; his memoirs focus on his professional career and public activities, and there are few allusions to personal matters. His political orientation shifted from progressive-liberal affiliations to conservatism, nationalism, and militarism. By the end of the First World War he was a member of a right-wing nationalist party and a local militia that fought against revolutionary Spartacists (radical communists who rebelled against the more moderate socialists), even though many of his attitudes remained politically liberal. Several nationalist and rightist statements in his memoirs, published in 1936, might be understood as a calculated strategy to overcome objections to other parts of its content in the Nazi era. ${ }^{8}$ But the biggest objection to Moll for the Nazis was that he was Jewish: a year before his death in 1939, his medical license was revoked. The books from his library were sold, and his unique historical collection of erotica disappeared. Only fragments of his correspondence and other personal papers have survived. ${ }^{9}$

${ }^{6}$ Andreas-Holger Maehle, "'God's Ethicist': Albert Moll and His Medical Ethics in Theory and Practice," Medical History 56, no. 2 (2012): 217-36, see 229.

7 Albert Moll, Ein Leben als Arzt der Seele: Erinnerungen (Dresden: Carl Reissner, 1936), 182-83, 188-89; Max Dessoir, Buch der Erinnerung (Stuttgart: Ferdinand Enke, 1946), 128-29; Heinz Goerke, "Albert Moll," in Berliner Ärzte Selbstzengnisse, ed. Heinz Goerke (Berlin: Berlin Verlag, 1965), 236-63, see 236; Volkmar Sigusch, Geschichte der Sexualwissenschaft (Frankfurt: Campus, 2008), 219-20; Andreas-Holger Maehle and Lutz Sauerteig, introduction to Medical History 56, no. 2 (2012): 123-32, see 129, 131-32; Andreas Sommer, "Policing Epistemic Deviance: Albert von Schrenck-Notzing and Albert Moll," Medical History 56, no. 2 (2012): 255-76, see 271.

${ }^{8}$ Moll, Ein Leben, 13-14, 65-66, 151-53, 196, 206, 210-31, 281; Albert Moll, "Der 'reaktionäre' Kongress für Sexualforschung," Zeitschrift für Sexualwissenschaft 13 (1927): 321-31, see 325 .

${ }^{9}$ Goerke, "Albert Moll," 241; Otto Winckelmann, "Albert Moll als Sexualwissenschaftler und Sexualpolitiker," in Sexualwissenschaft und Sexualpolitik: Spannungsverbältnisse in 


\section{KrafFt-Ebing's Influence on Moll}

Three monographs and two edited works document Moll's substantial contribution to sexology. Die Conträre Sexualempfindung (The contrary sexual feeling, 1891, with expanded editions in 1893 and 1899) was one of the first medical books exclusively devoted to homosexuality. His Untersuchungen über die Libido sexualis (Investigations of the sexual libido, 1897-98), which built on his earlier book, provided an explanatory framework of sexuality in general. In Das Sexualleben des Kindes (The sexual life of the child, 1908) he elaborated his views on childhood sexuality. His prominence in sexology was also evident in his editorship of the Handbuch der Sexualwissenschaften (Handbook of sexual sciences, 1912) and the updated and drastically revised 1924 edition of Richard von Krafft-Ebing's best seller Psychopathia sexualis, to which he added many of his own case studies and explanatory insights, as well as a review of the latest biological research on sexuality. ${ }^{10}$

From 1886 on, when the first edition of Psychopathia sexualis appeared, Moll was in touch with Krafft-Ebing, at that time a leading expert in sexual pathology. Moll's study about homosexuality carried a laudatory preface by Krafft-Ebing, who was also the most frequently quoted author in Moll's sexological works. They were on familiar terms and exchanged information about their professional interests and their case studies. ${ }^{11}$ Moll basically adopted Krafft-Ebing's sexual taxonomy. Although both researchers paid attention to a wide variety of sexual behaviors, including voyeurism, exhibitionism, bestiality, pedophilia, necrophilia, and coprolagnia, they focused on four fundamental forms of perversion. ${ }^{12}$ The first and foremost was

Europa, Amerika und Asien, ed. Rolf Gindorf and Erwin J. Haeberle (Berlin: Walter de Gruyter, 1992), 65-71, see 70; Otto Winckelmann, "Der vergessene Albert Moll (18621939) und sein 'Leben als Arzt der Seele," in Medizinische Wissenschaften und Judentum, ed. Nora Goldenbogen et al. (Dresden: Verein für regionale Politik und Geschichte, 1996), 46-52, see 48-50; Sebastian Pranghofer, "Albert Moll Sources and Bibliography," Medical History 56, no. 2 (2012): 296-306.

${ }^{10}$ Richard von Krafft-Ebing, Psychopathia sexualis: Mit besonderer Berïcksichtigung der konträren Sexualempfindung; Eine medizinisch-gerichtliche Studie für Ärzte und Juristen, ed. Albert Moll (Stuttgart: Ferdinand Enke, 1924). Moll's contributions are spread throughout the book. Moll revised and expanded the entire manuscript to the extent that he might be considered a coauthor of this edition. To highlight this fact, I have added his name as editor to subsequent citations of this book.

${ }^{11}$ Krafft-Ebing, Psychopathia sexualis, ed. Moll, iii-v; Moll, Ein Leben, 143-45; Albert Moll, "Nekrolog: Krafft-Ebing," Deutsche medizinische Presse 7 (1903): 14-15; Moll, "Krafft-Ebing," Die Zukunft 43 (1903): 463-68; Albert Moll to Richard von Krafft-Ebing, July 9, 1891, Nachlass Richard von Krafft-Ebing, Wellcome Library Archives, Wellcome Institute for the History of Medicine, London.

${ }^{12}$ See Richard von Krafft-Ebing, Psychopathia sexualis: Mit besonderer Berücksichtigung der conträren Sexualempfindung; Eine klinisch-forensische Studie (Stuttgart: Ferdinand Enke, 1891) and subsequent editions; Moll, Die Conträre Sexualempfindung, 55-155; Moll, Untersuchungen, 311-693. See also Henry Havelock Ellis and Albert Moll, "Die Funktionsstörungen des Sexuallebens," in Handbuch der Sexualwissenschaften: Mit besonderer 
contrary sexual feeling, or inversion, terms that referred to various physical and psychological fusions of masculinity and femininity and that sexologists such as Hirschfeld, and also Moll himself, would later differentiate into the categories of homosexuality, bisexuality, androgyny, transvestism, and transsexuality. The second was fetishism, the erotic obsession with certain parts of the body or objects. The third and fourth were sadism and masochism. The terms "homosexuality" and "heterosexuality" had been coined by the Austrian journalist and human rights campaigner Karl Maria Kertbeny at the end of the 1860s, but they were not yet in common use. It was Krafft-Ebing and Moll who revived their usage around 1890. Individual attraction to both sexes was not yet labeled as bisexuality but as psychic hermaphroditism. ${ }^{13}$

Just like Krafft-Ebing's works on sexuality, those of Moll were full of case histories, including (auto)biographical accounts and letters from patients and correspondents. ${ }^{14}$ However, Moll's explanatory reflections were far deeper and more elaborate than those of Krafft-Ebing, which were mainly fragmented comments on his many case histories and the opinions of other doctors. Moll used his cases as illustrations of a more thorough theoretical analysis. Yet even as he grappled with the full range of medical theories and social stereotypes about sexuality, Moll's thinking was far from static or coherent. His writing reveals him to have been a cautious, searching, and open-minded thinker, not shunning doubt and ambivalence and acknowledging that his knowledge was far from definitive. ${ }^{15}$

\section{Private Patients and the Homosexual Subculture}

Claiming that his scientific approach to homosexuality was free from prejudices and moralizing, Moll questioned several of the prevailing notions about it. ${ }^{16} \mathrm{He}$ doubted that same-sex desires could be acquired through behavioral

Berücksichtigung der Kulturgeschichtlichen Beziehungen, ed. Albert Moll (Leipzig: Verlag von F. C. W. Vogel, 1912), 603-740.

${ }^{13}$ Richard von Krafft-Ebing, Psychopathia sexualis: Mit besonderer Berücksichtigung der conträren Sexualempfindung: Eine klinisch-forensische Studie (Stuttgart: Ferdinand Enke, 1888), 88; Krafft-Ebing, Psychopathia sexualis (1889), 96; Moll, Die Conträre Sexualempfindung, passim.

${ }^{14}$ Moll's Untersuchungen über die Libido sexualis contains 78 case histories, the third edition (1899) of Die konträre Sexualempfindung has 42, and his edition of Krafft-Ebing's Psychopathia sexualis includes as many as 447. (Note that the first edition of Moll's book is entitled Die Conträre Sexualempfindung, but the title of the third edition is Die konträre Sexualempfindung.)

${ }^{15}$ See, for example, Albert Moll, "Neuropathologie: Die konträre Sexualempfindung," Internationales Centralblatt für die Physiologie und Pathologie der Harn- und Sexual-Organe 3 (1892): 423-27, esp. 425.

${ }^{16}$ Moll, Die Conträre Sexualempfindung, v-vi. See also Albert Moll, Die konträre Sexualempfindung: Mit Benutzung amtlichen Materials (Berlin W.: Fischer's medicinische Buchhandlung, H. Kornfeld, 1899), 584-94. 
influences such as seduction or masturbation. If such factors played a role at all, they should be viewed not as causes but as triggers revealing an underlying disposition. Although he referred to diffuse and ephemeral same-sex behavior in sex-segregated settings and during childhood and adolescence, Moll's central tenet was that in most cases homosexuality involved a deep-seated innate feeling that determined not only sexual desire but also personality. Referring to Krafft-Ebing's distinction between perversity (a contingent deviant sexual act of essentially normal individuals) and perversion (an irresistible and permanent innate inclination), he argued that the latter was strong enough to overwhelm all efforts of willpower, rational consideration, or moral consciousness and that inborn homosexuality should therefore not be considered immoral or illegal. These pragmatic arguments and his liberal principles led Moll to oppose the criminalization of what Paragraph 175 of the German penal code referred to as the "unnatural vice" of sexual acts between men or between human beings and animals. (Sex between women was not criminalized.) Prosecutions were arbitrary and ineffective as a deterrent, he argued, and criminalization subjected homosexuals to potential blackmail, social ostracism, and, if convicted, loss of civil rights. He insisted that homosexual acts between consenting individuals above the age of sixteen or eighteen that did not harm others or public decency should not be punishable. Dangerous sexual offenders, meanwhile, belonged in an asylum rather than a prison. ${ }^{17}$

It should be noted that although one-third of his case studies were of women, Moll's focus was on male homosexuality. Unlike other sexologists of his day, he assumed that lesbianism was as frequent as male homosexuality and in many ways similar, but his information about it was sparser. Lesbians were not as visible, vocal, and self-conscious as men; they were more often married; and because their sexual behavior was not punishable, lesbianism produced less social and political controversy. ${ }^{18} \mathrm{My}$ analysis of Moll's changing approach to homosexuality focuses on the male version.

Echoing Krafft-Ebing's characterization of homosexuals as "stepchildren of nature," Moll talked about "unfortunate human beings" who deserved compassion and fair treatment. Obtaining true knowledge about them depended on winning their confidence and taking their life experiences seriously. ${ }^{19}$ In several of the case histories and fragments from correspondence that he included in his study, homosexual men expressed themselves

${ }^{17}$ Moll, Die Conträre Sexualempfindung, 223-46; see also Moll, Untersuchungen, 694856; Albert Moll, "Die widernatürliche Unzucht im Strafgesetzbuch," Die Gesellschaft 15 (1899): 1-11.

${ }^{18}$ See Moll, Die Conträre Sexualempfindung, 246-66. See also Krafft-Ebing, Psychopathia sexualis, ed. Moll, 473-511. For a historical account of the treatment of lesbianism in sexology, see Heike Bauer, "Theorizing Female Inversion: Sexology, Discipline, and Gender at the Fin de Siècle," Journal of the History of Sexuality 18, no. 1 (2009): 84-102.

${ }^{19}$ Moll, Die Conträre Sexualempfindung, v-vi, 233. Translations of quotes from German into English are my own. 
about their outlooks, feelings, and experiences, and it appears that many of them viewed Moll's approach as supportive. In a letter to Krafft-Ebing, Moll mentioned the suffering of one of his patients, an "upper-crust young man," whose family had discovered the letters of his lover. Moll offered his help, but, as he wrote to Krafft-Ebing, his efforts to enlighten the relatives came up against the "usual wall of narrow-mindedness." ${ }^{20}$ Although undesirable character traits such as mendacity, jealousy, backbiting, cowardice, and vanity occurred frequently among homosexuals, he asserted, many of them were decent and worthy fellow citizens. ${ }^{21}$ Thus he praised one of his homosexual informers, "urning N.N.," for his "extraordinary objectivity." 22 N.N. was the pseudonym of the writer Adolf Glaser (1829-1915), who in 1878 had been involved in a scandal after his arrest, together with five other respectable men, by the Berlin police for violating Paragraph 175 . All of them were acquitted because the felony could not be proved due to a lack of evidence. ${ }^{23}$ Glaser disclosed his sexual life to Moll and may have informed him about homosexual meeting places in Berlin. ${ }^{24}$

Like Krafft-Ebing, Moll used the personal stories and information of patients and correspondents as an underpinning for his theoretical reflections. Unlike his Viennese colleague, Moll did not have access to patients in mental asylums, psychiatric clinics, and sanatoriums. He depended instead on private patients from the middle and upper classes who contacted him of their own accord and who, as articulate "clients," analyzed, explained, and even justified themselves. To be sure, he wrote, autobiographical accounts could suffer from distortions of wishful thinking, twisted memories, unconscious repression of experiences, or shame. One also needed to look out for retrospective projection under the influence of the current preoccupation with sexuality or familiarity with the increasingly available medical or other literature about it, literature that was likely to frame sexual life histories according to particular narrative patterns and scripts. Personal stories had to be rigorously verified and compared to the patient's fantasies and dreams. Yet Moll still insisted that personal experiences were crucial for understanding perversion, and he frequently drew on these life histories in his lectures and writings. ${ }^{25}$ In a lecture he gave on sexual psychology

${ }^{20}$ Moll to Krafft-Ebing, July 9, 1891.

${ }^{21}$ Moll, Die Conträre Sexualempfindung, 73.

${ }^{22}$ Ibid., $\mathrm{x}$.

${ }^{23}$ F. Hugländer [Hugo Friedländer], "Aus dem homosexuellen Leben Alt-Berlins," Jahrbuch für sexuelle Zwischenstufen 14 (1914): 45-63, esp. 61-63; Magnus Hirschfeld, Von einst bis jetzt: Geschichte einer homosexuellen Bewegung 1897-1922, ed. Manfred Herzer and James Steakley (Berlin: Rosa Winkel, 1986), 27. On N.N.'s true identity, see Robert Beachy, Gay Berlin: Birthplace of a Modern Identity (New York: Vintage Books, 2014), 58.

${ }^{24}$ Moll, Die Conträre Sexualempfindung, 35.

${ }^{25}$ For examples, see ibid., 193-94; Moll, Untersuchungen, 315; Krafft-Ebing, Psychopathia sexualis, ed. Moll, 678-89; Albert Moll, "Die Behandlung der Homosexualität," Jahrbuch für sexuelle Zwischenstufen 2 (1900): 1-29, esp. 16-17; Moll, Das Sexualleben des Kindes (Leipzig: Verlag von F. C. W. Vogel, 1908), 4-5; Moll, Ein Leben, 145. 
and pathology to physicians and medical students in 1912, for example, he showed his audience three writings by "sadists" and claimed that they were examples of his "fairly rich collection" of writings by "perverts." 26

Apart from his private practice, Moll also relied on his involvement in court cases and with the police and on his firsthand familiarity with the homosexual subculture in Berlin. The Berlin chief of the vice squad, Leopold von Meerscheidt-Hüllessem, who introduced a tacit tolerance for homosexual gatherings through police surveillance, gave Moll access to police files of registered homosexuals. ${ }^{27}$ Police officers escorted Moll on his fact-finding missions to bars, clubs, cruising venues, and masquerade balls, where cross-dressing was also common. In an 1891 letter to Krafft-Ebing, Moll described a "homosexual ball" he had just visited in tones suggesting that he enjoyed these excursions, and he noted that his informants from the world of prostitution enlightened him about the possibilities to satisfy perverse desires in this milieu, where fetishism, flagellation, and voyeurism appeared to be pervasive. ${ }^{28}$ The specific slang of the homosexual subculture, where members called each other schwul (gay or queer), Tanten (aunts), and Schwestern (sisters), was no secret to him. ${ }^{29}$ In an article in which Moll pondered how homosexuals recognized each other and secretly communicated through dress codes and sounds, he mentioned that he had gathered information among "different individuals from native and foreign cities," and he called on his readers to provide him with more facts. ${ }^{30}$ In a similar way, his curiosity was piqued when a transvestite consulted him. "Her appearance and gestures were fascinating," he reported in his memoirs, and he immediately invited himself to her home to pay her a visit. He found that she lived with a "gentleman" and had furnished the house like a "boudoir, in a more effeminate fashion than any high-society lady would have managed." 31

\section{Pathological, “Morbid-Like,” or Variation}

Moll did not doubt that homosexuality was a medical issue, but his evaluation of its pathological nature and of the associated physical causes was much

${ }^{26}$ Albert Moll, "Sexual-Psychologie und-Pathologie," Zeitschrift für ärztliche Fortbildung 9 (1912): $37-45,72-75$, see 44.

${ }^{27}$ Hirschfeld, Von einst bis jetzt, 27-28, 31, 38. Secondary accounts can be found in Robert Beachy, "To Police and Protect: The Surveillance of Homosexuality in Imperial Berlin," in After the History of Sexuality: German Genealogies with and beyond Foucault, ed. S. Spector, H. Puff, and D. Herzog (New York: Berghahn Books, 2012), 109-23; and Beachy, Gay Berlin, 54-59.

${ }^{28}$ Moll to Krafft-Ebing, July 9, 1891; Moll, Die Conträre Sexualempfindung, ix-xi, 8287; Albert Moll, "Die sozialen Formen der sexuellen Beziehungen," in Moll, Handbuch der Sexualwissenschaften, 309-460, see 380-87.

${ }^{29}$ Albert Moll, "Probleme in der Homosexualität," Zeitschrift für Criminal-Anthropologie, Gefüngniswissenschaft und Prostitutionswesen 7 (1897): 157-89, see 158.

${ }^{30}$ Albert Moll, "Wie erkennen und verständigen sich Homosexuelle untereinander?," Archiv für Kriminal-Anthropologie und Kriminalistik 9 (1902): 157-59.

${ }^{31}$ Moll, Ein Leben, 252. 
more cautious than that of other medical writers. Like other physiological and psychological functions, he explained, sexuality is characterized by considerable variation, and there are no absolute boundaries between the normal and the abnormal. Although many of the homosexuals he had encountered suffered from nervous conditions and were victims of heredity, he considered others to be perfectly healthy and without any trace of "degeneration" or other pathological symptoms. He argued that even if degeneration played a causal or predetermining role, it would not justify considering inborn homosexuality to be full-blown psychopathy. Using the qualification krankhaft (morbid-like), Moll compared homosexuality to more elusive disturbances such as hysteria and monomania, and he occasionally even referred to it as a sexual "variation." ${ }^{32}$ Moll used both of these terms in purposely ambivalent ways: krankbaft was meant to imply something less than health but still not full-blown illness, while a "variation" suggested that homosexuality in itself was not pathological. Mental and nervous distress among homosexuals, he added, could be caused by the social pressure and sexual frustration they endured, and gratification through homosexual intercourse seemed to be wholesome rather than harmful to their health. ${ }^{33}$

The ambiguity of Moll's argument is strikingly evident in an 1897 article about "problems of homosexuality" published in a criminological journal. He describes physical symptoms of gender inversion as signs of degeneration; claims that an exclusive homosexual orientation, without any trace of heterosexual desire or urge to procreate, is pathological; and asserts that only heterosexual intercourse is natural, since the anatomy of the male and female sex organs are "teleologically" tailored to each other. On the other hand, he admits that prominent experts - such as Wilhelm Griesinger, Carl Westphal, Krafft-Ebing, Valentin Magnan, Ellis, Edward Carpenter, and Marc-André Raffalovich — did not agree about homosexuality's degenerative causes or relation to other morbid symptoms. The association of homosexuality with illness in the medical world, he suggests, could be the consequence of self-selection: only those with complaints would consult a doctor, whereas others would remain invisible. Further undermining theories of pathology, Moll discusses the "florescence" of homosexuality during the golden age of ancient Greece. "Should we really believe," he rhetorically asks, "that this would only have been a result of degeneration?" An "unbiased consideration" did not allow the conclusion that homosexuality necessarily involved hereditary defects. Moreover, Moll also rejected the common argument that urbanization and moral decay had led to an increase in homosexuality in modern times. ${ }^{34}$

${ }^{32}$ Moll, Die Conträre Sexualempfindung, 131, 189-90, 202-4. See also Moll, "Probleme," 171-73; Moll, Untersuchungen, 543-46, 555-56, 626, 635, 644; Ellis and Moll, "Die Funktionsstörungen," 652; Krafft-Ebing, Psychopathia sexualis, ed. Moll, 396-99.

${ }^{33}$ Moll, Die Conträre Sexualempfindung, 240. See also Moll, Untersuchungen, 626, 635, 644.

${ }^{34}$ Moll, "Probleme," 171-74. See also Albert Moll, “Über den Einfluss des grossstädtisches Lebens und des Verkehrs auf das Nervensystem," Die Umschau: Übersicht über die Fortschritte 
Moll further tacitly undermined categorizations of homosexuality as a pathology by putting it on a par with heterosexuality, which he tended to consider as attraction and intercourse between males and females without any procreative intention. Whereas other medical authorities on sexuality, such as James G. Kiernan, considered such heterosexual behavior as perverse because it seemed to deviate from nature's purpose, Moll's frequent use of the term "heterosexuality" next to "homosexuality" implied a separation between sexuality and reproduction. Without ruling out heterosexual coitus and therefore procreation as the underlying natural aim of sexuality, he shifted the focus to its subjective, experiential dimension. His distinction between the sexual drive, of which people are subjectively aware, and the unconscious goal-oriented reproductive instinct was crucial. ${ }^{35} \mathrm{He}$ was unique in arguing that the instinct to reproduce was not relevant for an understanding of the sexual drive, which aimed for physical contact and coitus with a partner and involved attraction and physical and mental satisfaction. As his various writings make clear, for Moll this dimension of sexuality was the object of sexology; procreation was another-merely biomedicalmatter. The usual moral distinction between procreative and nonprocreative acts would give way to the modern focus on the differentiation of sexual desires.

Moll's analysis of the sexual drive questioned the assumption that it was inherently and exclusively heterosexual and that heterosexuality was the self-evident standard of normality. He argued that heterosexual and perverted individuals did not essentially differ in their autoerotic practices or their basic motivation for other sexual activities. The close connection between the sexual drive and the love impulse toward a specific individual, which distinguished humans from lower animals, was as prevalent among homosexuals as among heterosexuals, and, apart from the higher frequency of oral and anal sex among the former, the basic physiological processes leading to orgasm were the same. In line with what some of his clients made clear-that partnership was as important to them as sexual gratification-he noticed that the manner in which they experienced sexual passion as well as dating and love was in no way different from how heterosexuals felt these things. Neither did homosexuals distinguish themselves from heterosexuals through a particular preference for youngsters. In both groups only

und Bewegungen auf dem Gesamtgebiet der Wissenschaft, Technik, Litteratur und Kunst 6, no. 46 (1902): 926-53, see 932-33.

${ }_{35}$ Albert Moll, "Analyse des Geschlechtstriebes," Medizinische Klinik: Wochenschrift für praktische Ärzte 1, no. 12 (1905): 273-78, see 273-74; 1, no. 13 (1905): 302-4. For Moll's ambiguous stance about sexuality's natural goal and the interrelated issue of the either pathological or nonpathological nature of perversion, see also Moll, Die Conträre Sexualempfindung, 189-90, 202; Moll, "Probleme," 165, 171; Albert Moll, "Sexuelle Perversionen, Geisteskrankheit und Zurechnungsfähigkeit," Geschlecht und Gesellschaft 3, no. 1/2 (1908): 17-32, 65-78, see 26-27, 29-30; and Krafft-Ebing, Psychopathia sexualis, ed. Moll, 684-86. 


\section{Harry OOSTERHuis}

a minority showed such desire; therefore, there was no reason to equate homosexuality with "pederasty" or "pedophilia." 36 The basic similarities between the worlds of hetero- and homosexual prostitution also suggested, according to Moll, that both orientations were of the same kind. ${ }^{37}$

In nineteenth-century biomedical thinking, sexual desire was generally conceived as a secondary attribute of sex and explained in terms of the physical and mental attraction between contrasting male and female characteristics. Evolution had supposedly advanced an increasing distinction of males and females and their mutual polar attraction. According to this widely shared view, also among homosexual rights activists such as Karl Heinrich Ulrichs and Hirschfeld, "contrary sexual feeling," including homosexuality, deviated from the regular differentiation of the physical and mental characteristics of men and women: "urnings" were characterized by a female soul in a male body (or vice versa with regard to lesbians) and belonged to an intermediate "third sex."

Moll also used this explanation, but at the same time he cast doubt on the correlation between same-sex desire and physical, mental, and behavioral features of the opposite sex, such as the penchant for cross-dressing. Many homosexuals were entirely masculine in their appearance and behavior, he noticed, whereas effeminate men, including transvestites, could be found among heterosexuals. Homosexuality and gender inversion overlapped, Moll argued, but they were not identical. ${ }^{38}$ In his 1891 book, he used both "contrary sexual feeling" and "homosexuality," but by the time he wrote his Untersuchungen (1897-98), the term "homosexual" was more prominent, signaling a shift away from the understanding of same-sex desire as gender inversion to a notion of homosexual orientation centered on same-sex partner choice. Moll's separation of homosexual desire from its supposed dependence on contrasting poles of masculinity and femininity entailed a stricter demarcation as well as an extension of the homosexual category. First, he more clearly distinguished homosexual desire from androgyny, transvestism, and transsexuality, all of which had been subsumed under the current original label of contrary sexual feeling. ${ }^{39}$ Second, he suggested that men who engaged in same-sex intercourse might also take a male gender role without showing any characteristics of the opposite sex; this would imply that they could present as masculine while also being identified (or

\footnotetext{
${ }^{36}$ Moll, Die Contrüre Sexualempfindung, 70-71, 90-92, 105; and Moll, "Wie erkennen?," $157-58$.

${ }^{37}$ Moll, Die Conträre Sexualempfindung, 115-21.

${ }^{38}$ Ibid., 70-71, 150-56. See also Moll, Untersuchungen, 347, 514-15; Moll, "SexualPsychologie und -Pathologie," 43; Albert Moll, Behandlung der Homosexualität: Biochemisch oder psychisch? (Bonn: A. Marcus und E. Webers Verlag, 1921), 61.

${ }^{39}$ In his edition of Krafft-Ebing's Psychopathia sexualis, Moll stressed that contrary sexual feeling, in particular cross-dressing, should be discussed apart from homosexuality as a separate phenomenon - as a gender disorder rather than a sexual one. Krafft-Ebing, Psychopathia sexualis, ed. Moll, xii, 431, 458, 572-85, 669-70, 682, 687.
} 
identifying themselves) as homosexual. At the same time, this finding would raise Moll's concern, as will be explained in the sections to follow.

Another, even more consequential finding of Moll's research was that (other) sexual perversions occurred in the same way and to the same degree among homo- and heterosexuals. Ten years before Krafft-Ebing would make a similar argument, Moll insisted on the dichotomy of hetero- and homosexuality as the fundamental sexual categorization while distinguishing bisexuality as their stepchild and perversions as subvariations. ${ }^{40}$ In doing so, he began to emphasize the gender of one's sexual partner-other (hetero), same (homo), or both (bi) - as the organizing framework of modern sexuality. This was different from the perspective of other late nineteenth-century experts, such as Alfred Binet, who had argued that all aberrations could be understood in terms of fetishism. The essence of fetishism was the fixation on particular nonreproductive sexual preferences, such as a desire for a distinct physical type, body part, garment, type of fabric, or age category; for sex with animals or corpses; or for specific sexual acts, scripts, or settings. Moll's heterosexual/homosexual dichotomy foregrounded the relational dimension of sexuality instead of the distinction between procreative and nonprocreative sexual behavior, thus highlighting the satisfying release of physical excitement as well as psychic fulfillment in an affective bond. His understanding of hetero- and homosexuality helped to articulate the trend of emphasizing the ideals of intimacy, equality, reciprocity, and psychic interaction. In contrast, as Moll suggested, fetishism, and also other perversions such as masochism, sadism, and exhibitionism, was at odds with the relational dimension of sexuality because of its partial focus on particular acts, objects, and scenarios.

Moll's study of homosexuality also initiated a shift from a biological and physiological to a more psychological approach. Late nineteenth-century medical researchers had attempted to locate the causal factors of sexual aberrations in the body and to explain them in terms of heredity and degeneration. Moll doubted whether the sexual drive could be reduced to the physiological operation of the brain, nervous system, gonads, or hormones. Since there was no proof that the physiological functioning of homosexuals generally diverged from that of heterosexuals, the difference in their desire was to be found in psychic processes, in emotional arousal, perception, feelings, imagination, memory, fantasy, and dreams. He insisted that subjective inner life and personal history, not the body or behavior as such, were the decisive criteria for the diagnosis of perversion as well as of a "normal" sexual orientation. Mental processes affected the sexual organs rather than the other way around. Moll was one of the first to adopt a new

${ }^{40}$ Moll, Die Conträre Sexualempfindung, 122-48. See also Moll, Untersuchungen, 31920; and Richard von Krafft-Ebing, "Ueber sexuelle Perversionen," in Die deutsche Klinik am Eingang des 20. Jahrhunderts in akademischen Vorlesungen, ed. E. von Leyden and F. Klemperer (Berlin: Urban und Schwarzenberg, 1901), 6:113-54. 


\section{Harry OOSTERHuis}

style of reasoning, before Freud would do so, about perversions as functional disorders of a sexual drive that were situated in the personality instead of the body. Therefore, sexuality as a field of research did not belong to biology and medicine only but also to psychology, which so far, Moll regretted, had largely overlooked this basic life force. ${ }^{41}$

\section{Sexual Desire as a Transgressive Drive}

Moll's book about homosexuality marked a shift from the medical-psychiatric understanding of deviant sexuality as a derived, episodic, and more or less singular symptom of an underlying physical or mental disorder toward a consideration of perversion as an integral part of an autonomous and continuous sexual drive. Six years later he continued his argument with a wider exploration of sexuality in Untersuchungen über die Libido sexualis (1897-98). Here he argued that if the largely random sexual drive had a built-in natural aim at all, it was not reproduction but physical as well as mental pleasure and satisfaction. Perversions were variations ("modifications") of the sexual drive, and the diversity of individual preferences, he noticed, was boundless, making a complete catalog of all existing sexual urges basically unfeasible. ${ }^{42}$ Again and again Moll indicated that the categorization and delineation of sexual preferences - the central preoccupation in psychiatric sexology-was self-defeating because the everyday reality of sexual life showed endless individual variety and countless transitional forms and mixtures, for example, with regard to gender inversions, masculine and feminine responses, bisexual variants, fetishistic preferences, active and passive roles, and differences of age between sexual partners. The direction of desire varied not only between individuals but also within individuals over time. $^{43}$

${ }^{41}$ Moll, Die Conträre Sexualempfindung, 89-93, 181-84, 193, 222, 327-28, 51315, 620-24; Moll, Untersuchungen, 2, 89-93, 328, 542, 592-93, 620-25, 692; Moll, Behandlung der Homosexualität, 7-21; Moll, "Analyse des Geschlechtstriebes," 273; Albert Moll, "Vita sexualis," in Der erfolgreiche Mensch, ed. Ludwig Lewin (Berlin: Allgemeine deutsche Verlagsgesellschaft, 1928), 67-100, see 81, 84-86, 95-96, 99. See also Arnold I. Davidson, The Emergence of Sexuality: Historical Epistemology and the Formation of Concepts (Cambridge, MA: Harvard University Press, 2002). Davidson refers to a "new style of reasoning" about sexuality that parts with biological reductionism. Already before Freud, Davidson argues, psychiatrists had begun to turn the discussion away from explaining sexuality as a series of interrelated physiological events to a more psychological understanding. In their view, perversion was not so much rooted in physical as in so-called functional disorders. In this new psychiatric style of reasoning, perversions were disorders of an instinct that could not be precisely located in the body.

${ }^{42}$ Moll, Untersuchungen, 8-10, 24-29, 65, 398, 406-7, 581, 555-56, 581, 620, 689, 690.

${ }^{43}$ See, for example, Moll, Die Contrüre Sexualempfindung, 151; Moll, Untersuchungen, 481, 581; Moll, Behandlung der Homosexualität, 27; and Krafft-Ebing, Psychopathia sexualis, ed. Moll, 412-13, 639, 686. 
Regular and deviant sexualities were interconnected, Moll stressed, and could only be understood in their reciprocal relation. His study of homosexuality fueled his thought about heterosexuality, while his consideration of fetishism, sadism, and masochism explained aspects of normal sexuality. Fetishism was an intrinsic feature of normal sexuality because the specific individual preferences in sexual attraction and, connected to that, monogamous love were grounded in a distinct attraction to particular physical and mental characteristics of one's partner. Moll argued that whether fetishism should be considered to belong to regular sexuality or to be perverse depended on the degree to which the sensual preference for a specific feature or object had dissociated itself from a loved person and had become the exclusive motive for sexual gratification. Sadism and masochism appeared to be inherent in male and female sexuality in general, the former being of an active and aggressive nature and the latter of a passive and submissive one. ${ }^{44}$

The blurring of clear boundaries between the normal and the abnormal showed itself in particular in Moll's analysis of childhood sexuality, which in his view also clarified the nature of adult sexuality. Infantile sexual manifestations, including masturbation, homosexuality, and even fetishist, sadistic, or masochistic tendencies, were far from exceptional and in themselves not necessarily, as was widely believed, symptoms of perversion that were caused by either degeneration or seduction. In Das Sexualleben des Kindes (1908), Moll included several autobiographical case histories of "normal" adults whose infantile impulses had been irregular. ${ }^{45}$ The wide range of sexual impulses and activities found among children and adolescents was, according to Moll, part of a transitory stage from undifferentiated and erratic sexuality to a differentiated and constant drive that began between eight and ten years and could last until the age of around twenty-three. Eventually, the majority of adults would show a heterosexual desire, while a minority of them would exhibit a homosexual or bisexual one, and all of them possibly with specific perverse leanings.

\section{The Entanglement of Nature and Culture}

A central argument in Moll's Untersuchungen über die Libido sexualis is the differentiation of the sexual drive into a physical and a sociopsychological dimension on the basis of two fundamental partial drives: discharge

${ }^{44}$ Moll, Untersuchungen, 320, 429, 497; Moll, Die Conträre Sexualempfindung, 12531; Krafft-Ebing, Psychopathia sexualis, ed. Moll, 651-63; Albert Moll, "Physiologisches und Psychologisches über Liebe und Freundschaft," Zeitschrift für Psychotherapie und medizinische Psychologie mit Einschluss des Hypnotismus, der Suggestion und der Psychoanalyse 4 (1912): 257-78, see 265, 277.

${ }^{45}$ Moll, Das Sexualleben, 46-102. Many of Moll's insights about childhood sexuality can already be found in his earlier works: Moll, Die Conträre Sexualempfindung, 154-77; and Moll, Untersuchungen, 54-55, 420-23, 306-7, 427-29, 449-50, 497, 505. 
(Detumescenztrieb) and attraction (Contrectationstrieb). ${ }^{46}$ The first manifested itself in physical arousal and centered on the sexual act, whether with someone else or alone, as a means to release sensual energy and tension in orgasm. Discharge, which Moll conceptualized in terms of the male rather than the female sexual drive, was the result of an irresistible physiological force that builds up from inside the body and pushes persistently toward physical gratification. The attraction drive involved the relational aspect of sexuality: the love impulse toward a real or imagined partner and related to acts such as courting, touching, caressing, fondling, kissing, caring, and other expressions of affection, all of which showed the overlap between sexual and social feelings. Moll assumed that in human evolution the attraction drive had developed after the discharge drive. In individual development, however, either one could emerge first, and both would often manifest themselves independently well before and during puberty. In regular adult sexual life, the two drives generally would go together, but their separate operation was far from uncommon.

Moll's discussion of the attraction drive underlined the decisive role of mental factors in the development of relational sexuality. Physiological processes and abilities were nothing more than necessary preconditions for sexual functioning. Mental stimuli, such as imagination and fantasies, on the other hand, were crucial, since the satisfaction of the sexual urge was made up not only of physical release but also of emotional fulfillment. In Moll's analysis, sexuality emerged as an intricate complex of physical functions, reflexes, bodily sensations, behaviors, experiences, feelings, thoughts, mental associations, desires, fantasies, and dreams. ${ }^{47}$ In his explanation of the genesis of the sexual drive, Moll shunned monocausality and reductionism and proposed "conditional thinking," focusing on preconditions, potentials, and interactive causes and triggers. ${ }^{48}$ Against the dominant trend in biomedical thinking, he questioned the causal role of heredity and degeneration as well as the alternative idea that perversion was merely acquired by psychological association or the traumatic consequences of seduction. Foregrounding the interaction of nature and nurture - of physical and mental processes-Moll argued that heredity represented a potential rather than a predetermining cause of sexual drives, which were the result of possible "reaction capacities" or "reaction modes" that had to be incited by external stimuli and attachments to particular love objects. ${ }^{49}$ Sexual potential generally tended toward the opposite sex, but if this inclination was fragile or if it was malformed

${ }^{46}$ Moll, Untersuchungen, 10-25, 52-55.

${ }^{47}$ Ibid., 327, 581, 592, 620, 624-25, 692; and Moll, "Analyse des Geschlechtstriebes," $275-76,302$.

${ }^{48}$ Moll, Behandlung der Homosexualität, 6-21; Krafft-Ebing, Psychopathia sexualis, ed. Moll, 58-70, 457, 647.

${ }^{49}$ Moll, Untersuchungen, 306-8, 399, 406-7, 474-75, 505; Moll, Behandlung der Homosexualität, 22, 30; Krafft-Ebing, Psychopathia sexualis, ed. Moll, 632, 637, 660, 69092, 699-701. 
or hampered by environmental, behavioral, psychological, or sociocultural factors, then a susceptibility to homosexuality or sexual perversities could emerge. Moll argued that sensorial stimuli, mental association, education, and habit formation during childhood and adolescence were crucial for the outcome of the interplay between nature and nurture, ${ }^{50}$ and he stressed that this made the human sexual drive fundamentally different from and much more precarious and complex than the instinctual sexuality of animals. ${ }^{51}$ The implication was that not only moral standards and feelings of shame but also the sexual drive itself were largely shaped in culture and history. ${ }^{52}$

This evaluation of culture's impact was not without contradictions. On the one hand, Moll intimated that cultural development was in line with natural evolution: both favored heterosexual desire as the dominant mode of sexual potential. But this claim, grounded in a teleological understanding of evolution, was inconsistent with his denial of the naturalness of the heterosexual drive and with its separation from the reproductive instinct. Therefore, he also suggested that regular heterosexuality was not so much the result of a natural purpose but rather of the increasingly self-controlled style of civilized life, which entailed a domestication of erratic sexual impulses and their ever closer association, in the attraction drive, with love, partnership, marriage, family, and even broader social relations. ${ }^{53}$

On the other hand, Moll came to a different assessment of the bearing of civilization, one that cast doubt on the cultural primacy of relational heterosexuality. The historical, social, and individual diversity of sexual expressions and the universal prevalence of perversions showed that cultural refinement, beliefs, customs, lifestyles, and fashions inevitably modified and deformed the sexual drive. The artificiality of civilization had advanced not only the separation of sexual desire and procreation but also the continuing refashioning, amplifying, and heightening of sensual pleasure in multiple ways, including perverse ones. Man, he wrote, "seizes the most ingenious methods to heighten voluptuousness, which one rarely finds among animals. ... All of this shows most clearly how far man has drifted away from nature. ${ }^{" 54}$ The essence of perversion, according to Moll, was the complete

${ }^{50}$ Moll, Untersuchungen, 89-93, 306-8, 427-29, 497-505, 593; Moll, Die Conträre Sexualempfindung, 156-77; Moll, "Probleme," 163-69; Moll, "Die Behandlung der Homosexualität," 12-13; Moll, Behandlung der Homosexualität, 27-42; and Krafft-Ebing, Psychopathia sexualis, ed. Moll, 402-3.

${ }^{51}$ Moll, Untersuchungen, 398-99, 406; Moll, "Sexual-Psychologie und -Pathologie," 41; Krafft-Ebing, Psychopathia sexualis, ed. Moll, 632-36; and Moll, "Vita sexualis," 81, 84.

${ }^{52}$ Moll, Das Sexualleben, 231-33; Albert Moll, "Die sozialen Formen der sexuellen Beziehungen," in Moll, Handbuch der Sexualwissenschaften, 309-460; Moll, "Die Erotik in der Literatur und Kunst," in Moll, Handbuch der Sexualwissenschaften, 461-568; Moll, "Weitere Beziehungen des Sexuellen zur Kultur," in Moll, Handbuch der Sexualwissenschaften, 569-602; Moll, Polizei und Sitte (Berlin: Gersbach und Sohn Verlag, 1926), 8-10, 32-38.

${ }^{53}$ Moll, "Die sozialen Formen," 416-56; and Moll, "Weitere Beziehungen," 572.

${ }^{54}$ Moll, Untersuchungen, 406-7. See also Krafft-Ebing, Psychopathia sexualis, ed. Moll, 632-39, 649-50. 
substitution of the regular aim of the sexual drive (coitus) by its means (titillation and lust), which had become the goal in itself. Perversion thus exemplified how culture had deeply modified sexuality by intensifying its psychological dimension and symbolic meanings. ${ }^{55}$

Moll's understanding of the cultural dimension of sexuality was further complicated by his evaluation of its beneficial and harmful aspects. In his discussion of the attraction drive and in his contributions to medical guidebooks about marriage, he highlighted the constructive effect of relational sexuality on personal development and well-being as well as matrimonial and social harmony. For Moll, love as a social bond was inherently sexual, and he tended to value the affective aspects of sexuality as a wholesome purpose in their own right, although he added that amorousness was intrinsically transient and often caused personal distress. Moll criticized the double standard for men and women as hypocritical, and he stressed the importance of reciprocal sexual satisfaction in marriage, which implied that women should not play a passive role in intercourse-not "lie down like a piece of wood," as Moll phrased it-and should be able to experience orgasm. All of this implied that men should adjust their more or less crude sexual behavior to the more psychological and relational sexual needs of women. ${ }^{56}$

At the same time, however, Moll alluded to an inevitable tension between the cultural order and deep-seated and irresistible human needs for sexual gratification. ${ }^{57}$ While recognizing that prudery and unfulfilled desires could lead to personality flaws and nervous and mental complaints, he viewed sexuality's explosive and barely controllable nature as a threat to the moral and social order. The constant danger that the discharge drive, including its frequently transgressive, bizarre, and sometimes destructive manifestations, blindly overruled the relational attraction drive called for social constraints and self-control. Man seemed to be caught in an unending struggle between unruly passions and the need to tame them-a struggle that was related to the fundamental differences between male and female sexuality. Along with other sexologists of his day, Moll emphasized the antagonistic nature of male and female sexual urges and the danger posed by the unbridled

${ }^{55}$ Krafft-Ebing, Psychopathia sexualis, ed. Moll, 638-39, 648.

${ }^{56}$ Quoted in Krafft-Ebing, Psychopathia sexualis, ed. Moll, 819. See also Albert Moll, "Wann dürfen Homosexuelle heiraten?," Deutsche medizinische Presse 6 (1902): 41-43; Moll, "Perverse Sexualempfindung, psychische Impotenz und Ehe," in Krankheiten und Ehe: Darstellungen zwischen Gesundheitsstörungen und Ehegemeinschaft, ed. Hermann Senator and Siegfried Kaminer (Munich: J. F. Lehmann, 1904), 667-717, see 683, 692-93; Moll, "Sexuelle Hygiene und Ehe," in Die Ehe: Ibre Psychologie, Hygiene und Eugenik, ed. Max Marcuse (Berlin: A. Marcus und E. Webers Verlag, 1927), 274-88; Moll, "Sexuell abnorme Ehen," in Marcuse, Die Ehe, 525-34; Moll, "Vita sexualis," 69, 85-86, 88-89, 96, 98-99.

${ }^{57}$ Moll, Die Conträre Sexualempfindung, 3-4, 90-92, 240; Moll, Untersuchungen, 8, 29, 52-55, 65-66, 398, 406-7, 581, 587, 592, 620; Moll, Das Sexualleben, 189, 196-98; Moll, "Analyse des Geschlechtstriebes," 303; Albert Moll, "Vorrede," in Moll, Handbuch der Sexualwissenschaften, ii-x, see v; Moll, "Die sozialen Formen," 430. 
brutishness of male lust and its tendencies toward domination and violence. Male sexual aggression made "free love," the ideal of some of the more radical sexual reformers and feminists, a dangerous proposition for women, who required cultural norms and social arrangements to protect them. ${ }^{58}$ Moll also suggested that girls should, to a certain degree, develop strength and an independent attitude in order to be able to defend themselves. ${ }^{59}$

\section{Psychotherapeutic Treatment of Homosexuality}

Informed readers will by now have noticed that several of Moll's insights foreshadowed central tenets of Freud's psychoanalysis: the irresolvable tension between sexuality and civilization; the importance of the psychic dimension of sexuality; the existence of infantile sexuality; the nature of the libido as a fragmented pleasure drive; the explanation of normal heterosexuality as resulting from a conversion of undifferentiated and partly perverse impulses; and the idea that sexual restraint may turn into unhealthy repression and cause nervous complaints. Moll was clearly one of the authors who inspired the insights that Freud outlined in his Three Essays on the Theory of Sexuality (1905) and presented as a breakthrough. ${ }^{60}$ Yet Freud hardly acknowledged his indebtedness to Moll and instead accused him of plagiarism when the two met in 1909, a year after Moll had published his monograph on infantile sexuality. Moll consistently criticized Freud's dubious methods, feeble empirical underpinnings, and biased interpretations of case histories. ${ }^{61}$ But Moll's claim that psychoanalysis was not much more than a series of tricks and would soon become irrelevant failed to gain traction. Freud and his followers successfully propagated the self-fabricated myth that Freud was the innovative thinker about human sexuality and the sole "discoverer" of

${ }^{58}$ Moll, "Die sozialen Formen," 318-45; Moll, "Sexual-Psychologie und -Pathologie," 39; Albert Moll, "Sexualität und Charakter," Sexual-Probleme 10 (1914): 1-9, 97-114, 176-91, see 184-85; Moll, "Vita sexualis," 87-88; Moll, Polizei und Sitte, 9-12, 41-42, 107, 127. See also Dickinson, Sex, Freedom, and Power, 258-62; Leng, Sexual Politics.

${ }^{59}$ Moll, "Physiologisches und Psychologisches," 262.

${ }^{60}$ Sigmund Freud, Drei Abhandlungen zur Sexualtheorie (Vienna: Deuticke, 1905), 1, 27, 31, 36-7, 80. Moll's influence on Freud can be deduced from Sulloway's reconstruction of Freud's reading of Moll's Untersuchungen über die Libido sexualis and the thirty-six markings by Freud in his copy of the book. Frank J. Sulloway, Frend, Biologist of the Mind: Beyond the Psychoanalytic Legend (New York: Basic Books, 1992), 516-18, see also 254, 266, 301-2, 470-74. Freud's copy of Moll's work is housed at the Freud Museum, London (catalog number LDFRD 1378) and the markings can be found on 9, 10, 13, 18, 23, 29, 41, 44, 53, $77,83,93,135,190,193,221,283,315,316,318,320,325,351,371,386,399,421$, $425,440,444,474,477,491,546,672$ and 683. I am indebted to Bryony Davies, assistant curator of the Freud Museum, for her help.

${ }^{61}$ For Moll's criticism of Freud, see Albert Moll, "Die Behandlung sexueller Perversionen mit besonderer Berücksichtigung der Assoziationstherapie," Zeitschrift für Psychotherapie und medizinische Psychologie 3 (1911): 1-29, see 8; Moll, "Sexuelle Hygiene," in Moll, Handbuch der Sexualwissenschaften, 877-922, see 881-85; Moll, Ein Leben, 54-55, 67-90, 192-93; and Moll, Das Sexuelleben, 13, 82-84, 154-55, 171-72. 
its infantile manifestations. They helped guarantee that Moll's pioneering work would sink into obscurity. ${ }^{62}$

Even more significant for the fate of Moll's reputation in sexology was his troubled relationship with Magnus Hirschfeld. Around 1900 both were at the forefront of a liberal and humanitarian approach to homosexuality. Moll's categorization of it as "morbid-like" and occasionally also as a variation was not very different from Hirschfeld's claim that it was a "deviation from the normal drive" but one that "is different from illness according to the current meaning" and his comparison of this orientation with harmless inborn malformations such as color blindness, a harelip, or naval rupture. ${ }^{63}$ Showing understanding for the "agitation" of homosexuals to improve their lot, Moll was among the first to sign Hirschfeld's Petition to the German Parliament (1897) advocating the abolition of Paragraph 175, and he contributed to and praised his Jabrbuch für sexuelle Zwischenstufen, although he stressed that Hirschfeld's claim about the inborn and fixed nature of homosexuality was premature. ${ }^{64}$ Moll also questioned the assumption of Hirschfeld and his followers that the widespread aversion to homosexuality among the general population would disappear once Paragraph 175 was abolished and the public was educated about its natural causes. ${ }^{65}$

Moll's respect for Hirschfeld, however, did not last long. Soon he was repeatedly debasing Hirschfeld's work, as well as accusing him and his associates of irresponsibly popularizing sexological knowledge and spreading harmful propaganda about homosexuality that would endanger the scientific

${ }^{62}$ See Herman Nunberg and Ernst Federn, eds., Protokolle der Wiener psychoanalytischen Vereinigung (Frankfurt: S. Fischer, 1977), 39-47; Ernest Jones, The Life and Work of Sigmund Freud: Vol. 2 Years of Maturity 1901-1919 (New York: Basic Books, 1955), 46, 104, 114; Volkmar Sigusch, "The Sexologist Albert Moll—between Sigmund Freud and Magnus Hirschfeld," Medical History 56, no. 2 (2012): 184-200, see 188-92; Lutz D. H. Sauerteig, "Loss of Innocence: Albert Moll, Sigmund Freud and the Invention of Childhood Sexuality around 1900," Medical History 56, no. 2 (2012): 156-83, see 158, 167-68, 180-82.

${ }^{63}$ Th. Ramien [Magnus Hirschfeld], Sappho und Sokrates, oder Wie erklärt sich die Liebe der Männer und Franen zu Personen des eigenen Geschlechts? (Leipzig: Max Spohr, 1896), 15, 130; see also Magnus Hirschfeld, Die Homosexualität des Mannes und des Weibes (Berlin: Louis Marcus, 1914), 391.

64 "Petition an die gesetzgebenden Körperschaften des deutschen Reiches behufs Abänderung des Paragraphen 175 des R.-Str.-G.-B. und die sich daran anschliessenden Reichstags-Verhandlungen," Jabrbuch für sexuelle Zwischenstufen 1 (1899): 238-66, see 257; Moll, "Die widernatürliche Unzucht im Strafgesetzbuch," 7; Moll, "Die Behandlung der Homosexualität"; Albert Moll, "Sexuelle Zwischenstufen," Die Zukunft 40 (1902): 425-33; Moll, "Sexuelle Zwischenstufen," Zeitschrift für ärztliche Fortbildung 1 (1904): 706-9. See also Moll, "Inwieweit ist die Agitation zur Aufhebung des Paragraphen 175 berechtigt?," Deutsche medizinische Wochenschrift 33 (1907): 1910-12; Hirschfeld, Von einst bis jetzt, 89, 108.

${ }^{65}$ Moll, "Inwieweit ist die Agitation," 1911; and Albert Moll, "Homosexualität und sogenannter Eros," in Verhandlungen des internationalen Kongresses für Sexualforschung, Berlin vom 10. bis 16. Oktober 1926, ed. Max Marcuse (Berlin: A. Marcus und E. Webers Verlag, 1928), 4:136-46, esp. 137, 143-44. 
stature of the new field. This shift in attitude toward Hirschfeld came at precisely the same time as the transformation of Moll's approach to homosexuality. While in the 1890s he had viewed the homosexual disposition as deep-rooted and mostly unchangeable, by 1900 he increasingly stressedalthough not without reservations - that homosexuality was pathological and malleable and that there were options for prevention and treatment. ${ }^{66}$

In the 1890s Moll had been hesitant about possible cures for homosexuality ${ }^{67} \mathrm{He}$ had seen no evidence that moral preaching, behavior modification, or somatic treatments such as castration and hormonal treatments could have any effect. "One simply cannot fight feelings and drives with hydrochloric acid or with aloes," he wrote, "one can only modify feelings and drives through similar psychic processes." ${ }^{" 68}$ If therapy was feasible at all, he initially believed, psychological remedies (such as hypnosis and suggestion, which affect inner life), feelings, and imagination should be tried. That some homosexuals were able to have "normal" intercourse by activating heterosexual fantasies (if contrary to their urges) proved the crucial role of psychic processes ${ }^{69}$ However, he balanced any therapeutic optimism with an emphasis on the frequently deep-rooted nature of homosexual desire. Attempts to pursue heterosexual intercourse (for example, with a prostitute) or marriage in order to quell homosexual orientation were pointless. ${ }^{70}$ Moreover, he had learned that many homosexuals - in particular those who were influenced by homosexual activism - were not motivated to be cured, and he became convinced that involuntary treatment was inevitably ineffective. ${ }^{71}$

Moll's intensive engagement with hypnosis and suggestion, which had already begun at the start of his medical career in the late 1880s, first fueled a psychological understanding of homosexuality and a decade later his belief that it could be treated in a psychological way. In 1900 he published an article in Hirschfeld's yearbook claiming that his experience as a therapist had proven the usual arguments of the opponents of Paragraph 175-that homosexuality was inborn, natural, and unchangeable-to be untenable. ${ }^{72}$ Whether homosexuality, which he now labeled not only as "morbid-like" but

${ }^{66}$ Ironically, Moll first expressed his changing views in the pages of Hirschfeld's own journal: Moll, "Die Behandlung der Homosexualität."

${ }^{67}$ Moll, Die Conträre Sexualempfindung, 207-22. See also Krafft-Ebing's preface, vii.

${ }^{68}$ Moll, Die Conträre Sexualempfindung, 222. See also Moll, "Die Behandlung der Homosexualität"; Moll, "Die Behandlung sexueller Perversionen"; and Moll, Behandlung der Homosexualität, 7-21.

${ }^{69}$ Moll, Untersuchungen, 542; Moll, "Analyse des Geschlechtstriebes," 302.

${ }^{70}$ Moll, "Die Behandlung der Homosexualität," 23, 27-28; and Moll, "Die Behandlung sexueller Perversionen," 10-11. See also Krafft-Ebing, Psychopathia sexualis, ed. Moll, 702-8.

${ }^{71}$ Moll, "Die Behandlung sexueller Perversionen," 24.

${ }^{72}$ Moll, "Die Behandlung der Homosexualität," $1-2,29$. See also Moll, "Die Behandlung sexueller Perversionen," 1, 24-25; Ellis and Moll, "Die Funktionsstörungen," 654-73; Moll, "Homosexualität und sogenannter Eros." 
actually "pathological," ${ }^{73}$ was inborn or acquired-a distinction he viewed as problematic, given the undifferentiated nature of sexuality during adolescence-was not relevant for its curability. Even if homosexuality were not pathological, Moll insisted, there were other valid reasons for therapy: the feeling of being rejected by society; the fear of social ostracism; conflicts with relatives; or the desire for marriage, family life, and children. On the basis of their contractual relationship, therapists were obliged to meet such needs of "clients" and gear treatment toward their individual condition, situation, and wishes. ${ }^{74}$ If the perverse orientation could not be remedied itself, there was still the possibility to treat related nervous and mental complaints or to subdue the sexual drive's high intensity ("hyperesthesia") through the prescription of bromine, hydrotherapy, physical exercise, diversion, or sublimation. ${ }^{75}$

Ten years later Moll admitted that hypnosis had not proved itself to be a very successful method for treating sexual perversions. ${ }^{76}$ Association therapy in combination with the training of willpower seemed more promising, in particular in cases where perversions originated from a mental fusion of particular sensual stimuli and sexual excitement or the fixation on specific fantasies. His goal was to supplant undesirable associations with appropriate ones, which could be activated through environmental stimuli and "normal" fantasies and connected to latent heterosexual "reaction capacities." ${ }^{77}$ Regular socializing with members of the other sex and heteroerotic incitements - for example, by reading erotic novels and regular visits to the theater, cinema, and art museums-would help homosexual men and women to modify their sexual imagination and fantasy life or, as Moll phrased it, their "mental masturbation.",78 "The somewhat loose depiction of a woman, the sensually arousing imagery of a boudoir or a harem, as these are not uncommon in erotic, but also in ordinary fiction, will often benefit such cases." ${ }^{79}$ It was essential, he insisted, to end sex segregation in schools and other educational institutions and to facilitate the kind of casual contact between young men and women that he had observed in the United States. Also, the sexual instruction of children by parents and educators should not be moralistic and repressive but realistic and positive in order to encourage heterosexual development. ${ }^{80}$ Moll appeared to believe that homosexual leanings could be subdued by stimulating heterosexuality, not only on an individual basis but also in society at large.

${ }^{73}$ Moll, "Sexuelle Zwischenstufen" (1902), 433.

${ }^{74}$ Moll, "Die Behandlung der Homosexualität," 3-5, 8, 18, 29.

${ }^{75}$ Ibid., 24-25; and Moll, "Die Behandlung sexueller Perversionen," 28.

${ }^{76}$ Moll, "Die Behandlung sexueller Perversionen," $1-2$.

${ }^{77}$ Ibid., 1-2, 12-16, 20-22, 26; and Moll, Ein Leben, 57, 150.

${ }^{78}$ Moll, "Die Behandlung der Homosexualität," 19, 23; and Moll, "Die Behandlung sexueller Perversionen," 10-11, 16-19, 23, 26.

${ }^{79}$ Moll, "Die Behandlung sexueller Perversionen," 18.

${ }^{80}$ Moll, Das Sexualleben, 223-94; Moll, "Sexualität und Charakter," 182-86; and Albert Moll, "Die nordamerikanische Volksschule," Die Zukunft 28 (1899): 88-91. 
Despite his claim that he had cured many of his clients of their homosexual leanings and that several of them had found happiness in marriage, he acknowledged that therapeutic results had to be put into perspective. Doctors should be realistic and could not always expect "a perfect effect" or any cure at all. ${ }^{81}$ In his memoirs he disclosed that his mode of association therapy found little resonance because it required a rare degree of strength and persistence. ${ }^{82} \mathrm{He}$ had discovered that even perversions acquired through habit and psychosocial factors were resistant to treatment, particularly in older clients already past the more pliable stage of undifferentiated sexuality. "There are influences of life, which hardly can be affected later," he admitted. ${ }^{83}$

Despite such reservations, Moll's changing view of homosexuality was colored by his therapeutic ambitions: offering treatment for sexual problems to private patients was an essential part of his professional profile and livelihood. Many homosexual men, including those seeking a cure for their leanings, placed their trust in him, suggesting that the interactions in his consultation room were more friendly and sympathetic than his public utterances. Moll may have been authoritarian, but he was straightforward and pragmatic rather than moralistic or dogmatic; again and again he denounced ignorance about and denial of facts about sexuality as well as hypocrisy, and he consistently balanced negative statements about homosexuals with the insistence that not all of them should be lumped together and that one should be wary of hasty and undeserved judgments. ${ }^{84}$

\section{Age Disparity}

Despite these views, after the 1890s the relatively sympathetic perspective on homosexuality that Moll had developed through exposure to the individual life stories of his clients was replaced with a more distant and stereotyped view of homosexuals as a group that was influenced by his growing aversion to their activism and subculture. He began to maintain that particularly those who were effeminate often exhibited "the most despicable characteristics," such as fickleness, petulance, coquetry, vanity,

${ }^{81}$ Moll, Ein Leben, 58, 149-51. See also Moll, "Die Behandlung der Homosexualität," 20, 29; Moll, Behandlung der Homosexualität, 45-63.

${ }^{82}$ Moll, Ein Leben, 57-58. See also Moll, "Die Behandlung der Homosexualität," 19; Moll, "Die Behandlung sexueller Perversionen," 24.

${ }^{83}$ Moll, "Die Behandlung sexueller Perversionen," 21-22, 26.

${ }^{84}$ Moll, Die konträre Sexualempfindung (1899), 594; Moll, "Perverse Sexualempfindung, psychische Impotenz und Ehe," 693; Moll, "Sexualität und Charakter," 176-83; Moll, "Die widernatürliche Unzucht im Strafgesetzbuch," 8-9; Moll, "Sexuelle Zwischenstufen" (1904), 709; Moll, Behandlung der Homosexualität, 64, 66; Krafft-Ebing, Psychopathia sexualis, ed. Moll, 423-25. See also Hirschfeld, Von einst bis jetzt, 80, 108, 149; and Manfred Herzer, "Albert Moll," in Homosexualität: Handbuch der Theorie- und Forschungsgeschichte, ed. Rüdiger Lautmann (Frankfurt am Main: Campus Verlag, 1993), 60-65. 
backbiting, sneakiness, insincerity, cowardice, and criminal leanings, and that there were many intriguers, liars, and cheats among them. Some of his more respectable and reliable homosexual informants, Moll claimed, were of the same opinion. ${ }^{85}$ Moreover, he added, many of them felt attracted to children and youngsters and were likely to abuse them and lure them into homosexual vice and prostitution-assertions at odds with his views in the 1890s. Whereas Moll had initially argued that public opinion should not be relevant for the legal judgment of homosexuality, he now tended to agree with, as he put it, "the healthy sentiment of the people," which would always put homosexuality below heterosexuality. ${ }^{86}$

Worrying about the vulnerability of youths, whose psychosexual development he believed to be undetermined and malleable until the age of around twenty-three, Moll increasingly pictured homosexuality as socially dangerous because he believed that it could be spread through seduction, corruption, contagion (in particular in sex-segregated institutions), and even agitation and propaganda. He was disturbed that Hirschfeld's Scientific-Humanitarian Committee, formed in 1897 to lobby for the repeal of Paragraph 175, had succeeded in reaching the masses and fueling public debate through its mass mailings, petitions, pamphlets, questionnaires, and surveys. Moll believed that this material's misleading message that homosexuality should be accepted because it was an inborn, fixed, and clearly distinguishable condition would not only discourage many individuals from seeking treatment but also incite more and more youngsters, with their impressionable minds, to ponder their possible homosexual leanings and to be lured into such a lifestyle ${ }^{87}$ His earlier acknowledgment of the sexual drive's randomness and fluidity, particularly among young people, and his insight that heterosexual desire was not fixed throughout life had morphed into a fear of recruitment and its dangers for relational heterosexuality. He now argued that homosexual emancipation and its public visibility could prevent young people from transforming their still amorphous inborn sexual reaction capacity and infantile impulses into heterosexual desire.

Many of Moll's newfound fears centered on the prevalence of age difference in homosexual contacts, and he was particularly concerned about the attraction of adult men to prepubescent boys and adolescents. Biomedical and also emancipatory thinking generally foregrounded the notion of homosexuality as a more or less exclusive orientation based on gender inversion ("uranism" or "contrary sexual feeling"), thus moving away from older patterns of same-sex intercourse ("pederasty" and "sodomy") involving

${ }^{85}$ Moll, "Sexualität und Charakter," 176-77.

${ }^{86}$ Moll, "Die widernatürliche Unzucht im Strafgesetzbuch," 2-4, 7; Moll, "Homosexualität und sogenannter Eros," 143-44. See also Moll, Das Sexualleben, 179; Moll, Ein Leben, 152; Moll, Behandlung der Homosexualität, 23-26.

${ }^{87}$ Moll, "Die Behandlung der Homosexualität," 1-2, 29; Albert Moll, "Paragraph 175," Die Zukunft 51 (1905): 412-13; Moll, Das Sexualleben, 179-81, 241, 247, 275-76, 285; Moll, “Der 'reaktionäre' Kongress,” 323-24; Moll, Ein Leben, 145-49, 152-53. 
age inequality as well as a hierarchical division of active and passive roles. Krafft-Ebing's coining of the term "pedophilia" in 1896 exemplified how medical experts and advocates of homosexual rights increasingly defined the desire for immature boys (and girls) as a seriously pathological and criminal category that was distinct from fully consensual versions of both heterosexuality and homosexuality. ${ }^{88}$ But the relationship between pedophilia and homosexuality remained a point of contention, and the public perception that homosexuals were responsible for the abuse and corruption of boys and youths troubled the struggle for decriminalization and social acceptance. The definition of homosexuality that Hirschfeld and his followers were attempting to project, with its emphasis on equality, reciprocity, and mutual consent, was at odds with older patterns of cross-generational and hierarchical same-sex behavior, which used to be understood as a manifestation of unbridled male lust. ${ }^{89}$

Age disparity in (homo)sexual attraction is not prominent in the main sexological works that Moll published in the 1890s. Although he questioned whether same-sex desire was always inborn and could be explained as gender inversion, as Ulrichs, Hirschfeld, and others believed, he suggested that it was characteristic of a distinct minority. In his Conträre Sexualempfindung he stated that the large majority of homosexuals do not desire young boys, just as most heterosexual men do not lust after immature girls. Moll substantiated this assertion by referring to a historical shift in the dominant sexual taste among homosexuals in Northern Europe: a preference for mature men had replaced the ancient Greek pattern of cross-generational sexual intercourse, which was still current in the Mediterranean and the Middle East. ${ }^{90}$ In the 1890s Moll categorized a desire for immature girls and boys as a rather occasional and more or less extreme and perverted complication of both hetero- and homosexuality to be placed in the same category as other exceptional aberrations such as sexual arousal by statues or dead bodies (necrophilia).

From 1900 on Moll began to pay much more attention to the role of age differences in homosexual attraction. His views demonstrate how worries

${ }^{88}$ Richard von Krafft-Ebing, "Ueber Unzucht mit Kindern und Pädophilia Erotica," Friedreichs Blätter für gerichtlichte Medizin und Sanitätzpolizei 47 (1896): 261-83.

${ }^{89}$ Jana Funke, "We Cannot Be Greek Now': Age Difference, Corruption of Youth and the Making of Sexual Inversion," English Studies 94 (2013): 139-53; Diederik F. Janssen, "Karl Heinrich Ulrichs: First Theorist of Erotic Age Orientation," Journal of Homosexuality 64, no. 13 (2017): 1850-71; Janssen, "Uranismus complicatus: Scientific-Humanitarian Disentanglements of Gender and Age Attractions," Journal of the History of Sexuality 27, no. 1 (2018): 101-33. The articles by Janssen have drawn my attention to the importance of age disparity in Moll's changing view of homosexuality.

${ }_{90}$ Moll, Die Conträre Sexualempfindung, 101-2, 146-48. Around 1895 Moll traveled in Egypt, the Ottoman Empire, Greece, and the Balkans. He published an article about the conditions in mental asylums in this part of the world and did not refer to sexual mores. Albert Moll, "Irrenanstalten des Orients," Deutsche medizinische Wochenschrift 21 (1895): $133-35,162-65$. 
about intergenerational contacts continued to frame explanations and judgments of homosexuality, in particular with regard to questions about its fixed or acquired and changeable nature, its delineation from heterosexuality, and its social acceptability. These preoccupations, which involved anxiety about the spread of homosexuality through seduction and corruption of youths, can be understood against the background of his conceptualization of childhood sexuality and adolescence as a critical and decisive period in sexual development, as well as discussions about the age of consent.

Moving away from his earlier emphasis on homosexuality as the label for a clearly delineated minority, Moll began to emphasize that same-sex desire and behavior were multifarious and to a large extent diffuse and fleeting. He also maintained that adult homosexuals were predatory and predominantly desired prepubescent boys and adolescents, who were extremely vulnerable to seduction and could be lured into homosexuality. With such claims Moll once more took a stand against Hirschfeld. In his study Die Homosexualität des Mannes und des Weibes (The homosexuality of the man and the woman, 1914), Hirschfeld distinguished four age-related categories of homosexual desire in their relative percentages: 5 percent of all homosexual men were attracted to immature boys ("pedophiles"), 45 percent to maturing youths ("ephebophiles"), 45 percent to adult men ("androphiles"), and 5 percent to seniors ("gerontophiles"). Hirschfeld tried to normalize ephebophilia and androphilia while designating pedophilia as a pathological and degenerative condition that needed medical treatment. ${ }^{91}$ Similar to Moll's previous arguments, Hirschfeld stressed that a preference for prepubescent children was as rare among homosexuals as it was among heterosexuals. Setting a small pedophilic minority apart from other homosexuals was of crucial importance for acquiring social and political support in the struggle for legal reform. Yet Hirschfeld's admission that 45 percent of homosexuals were attracted to young men between the age of fourteen and twenty-one (the ephebophiles) remained disconcerting with regard to the contested boundary between pubescence and maturity and the related age of consent. All of this likely prompted the authors of the petition for the repeal of Paragraph 175 to suggest raising the age of consent from fourteen to sixteen for both girls and boys. Along with the prominent psychiatrist Emil Kraepelin and others, Moll, however, accused Hirschfeld of continuing to downplay the danger of the seduction of youth and proposed even higher ages of consent, between eighteen and twenty-one..$^{92}$

${ }^{91}$ Magnus Hirschfeld, Die Homosexualität des Mannes und des Weibes (Berlin: Louis Marcus, 1914), 281; see also Hirschfeld, "Vom Wesen der Liebe: Zugleich ein Beitrag zur Lösung der Frage der Bisexualität," Jahrbuch für sexuelle Zwischenstufen 8 (1906): 1-284, 198.

${ }^{92}$ Moll, "Der 'reaktionäre' Kongress," 323-24; Florian Mildenberger, "Kraepelin and the 'Urnings': Male Homosexuality in Psychiatric Discourse," History of Psychiatry 18, no. 3 (2007): 321-35. 
By the 1920s Moll also presented a classification of four age categories for homosexual desire. The groups were more or less the same as those of Hirschfeld, but, and this was crucial, Moll's statistics were significantly different. Claiming to have examined five hundred individual casesthough without explaining his methodology-Moll concluded that at least between 10 and 12 percent of homosexuals preferred immature boys (unreife Knaben, under fourteen), 55 percent favored half-mature young men (Halberwachsenen, between fifteen and twenty), 30 percent were attracted to fully mature men (ausgereifte Männern), and only 2 or 3 percent preferred elderly men (Greisen). Two-thirds of all adult homosexual men, Moll therefore stressed, were attracted to young men and boys, and only one-third, those attracted to adult or elderly men, showed full gender inversion and a distinct homosexual personality. ${ }^{93}$ This indicated to him that in most cases homosexual leanings were not inborn in the sense of excluding the (more or less latent) presence of heterosexual "reaction capacities." External and situational influences, which explained the frequency of pedophilic behavior among teachers, and life experiences, in particular during the sexually undifferentiated stage, played a crucial role in the genesis of homosexual leanings. The same-sex attraction of adults to youngsters was often, Moll believed, the consequence of an acquired fixation of the frequent and usually ephemeral homosexual interest in peers, which was part of the still-undifferentiated sexuality of adolescents. ${ }^{94}$

Although the homosexual preference of adult men for boys and adolescents was, in his view, not based on gender inversion, Moll did explain their desire in gendered terms: the underlying mechanism of sexual attraction was, after all, the polarity between masculinity and femininity. Such men, he argued, were attracted to the less masculine features of youngsters: their beardless and smooth faces and their soft skin, which more or less resembled those of women. ${ }^{95} \mathrm{He}$ therefore categorized these noninverted men as not exclusively homosexual, since their predilections were more like heterosexual male attraction to women than like the gender invert's feminine desire for a masculine partner. Moll's focus on cross-generational desire as part and parcel of a form of homosexuality that was diffuse and did not rule out heterosexuality underlined his criticism of the idea, propagated by Hirschfeld for political purposes, according to Moll, that it was a permanent anthropological category. Most homosexual behavior, Moll argued, was not

${ }^{93}$ Moll, "Probleme," 159; Moll, Untersuchungen, 190-91, 478-84; Moll, "Perverse Sexualempfindung, psychische Impotenz und Ehe," 680-85; Moll, "Sexual-Psychologie und -Pathologie," 43; Moll, Behandlung der Homosexualität, 23-26; Krafft-Ebing, Psychopathia sexualis, ed. Moll, 404-5, 520-21, 666-69, 685, 716.

${ }^{94}$ Moll, Untersuchungen, 190-94, 477-82.

${ }^{95}$ Ibid., 478-84; Moll, "Perverse Sexualempfindung, psychische Impotenz und Ehe," 680-85; Moll, Behandlung der Homosexualität, 24-26; Krafft-Ebing, Psychopathia sexualis, ed. Moll, 520-21, 666-69, 685, 716. 
rooted in a clearly delineated unitary homosexual personality determined by gender inversion. ${ }^{96}$

All of this was in line with his claim that the majority of homosexuals could be treated and cured because their sexual reaction capacities held the possibility of "building bridges," as Moll phrased it, to their latent heterosexual leanings. He noted some sort of paradox here. Whereas the legal and social implications of (homo)sexual contacts with minors were more serious than those of same-sex intercourse between consenting adults, the prognosis of psychotherapeutic treatment of pedophiles and ephebophiles was more promising than curative efforts targeted at homosexuals who engaged in more age-equal relations. ${ }^{97}$

\section{Forensic Issues}

Moll's opposition to Hirschfeld was further fueled by their different approaches as expert witnesses in court cases dealing with violations of Paragraph 175. Although Moll never changed his view that this law was untenable ${ }^{98}$ he criticized Hirschfeld's efforts to exonerate offenders from conviction and the argument that Hirschfeld used to put forward in court: the contention that they could not be held accountable for their behavior because their homosexuality was innate. Hirschfeld appealed to Paragraph $5 \mathrm{l}$ of the German penal code, which stipulated that defendants who were diagnosed with mental disturbances or a state of unconsciousness and who had committed felonies under the influence of these conditions could be considered not responsible for their actions and therefore acquitted. Moll thought that this strategy was inconsistent: whereas Hirschfeld generally emphasized that homosexuality was part of nature and should not be considered pathological, as an expert witness he in fact suggested the opposite, Moll argued, because his recurrent appeal to Paragraph 51 implied the assumption that the mental state of homosexual offenders was similar to that of mental patients. Rather ironically, Moll countered Hirschfeld by stressing that homosexuality by and large was not such a serious psychopathological condition that it justified the application of Article 51; most homosexual offenders showed a reasonable mental condition and they thus had to be considered responsible for their actions. Moreover, as Moll insisted, the forensic expert should provide objective medical information about the mental state of defendants without considering the legal verdict, which belonged to the jurisdiction of lawyers. Hirschfeld again and again overstepped his

${ }^{96}$ Moll, Behandlung der Homosexualität, 44; Krafft-Ebing, Psychopathia sexualis, ed. Moll, 430, 669-70.

${ }^{97}$ Moll, "Perverse Sexualempfindung, psychische Impotenz und Ehe," 680-85; KrafftEbing, Psychopathia sexualis, ed. Moll, 716.

${ }^{98}$ Moll, Behandlung der Homosexualität, 67-68; Krafft-Ebing, Psychopathia sexualis, ed. Moll, 717-18, 774-76; Moll, "Der 'reaktionäre' Kongress," 323-24; Moll, Polizei und Sitte, 109-11. 
bounds as a medical expert by trying to sway the court, thereby providing a contradictory view of homosexuality. On the one hand he defined it as an inborn condition that was not pathological, but on the other he argued that homosexual offenders were not fully responsible for their sexual behavior, inferring mental impairment in order to convince the court to apply Article 51. Moll conversely held that whatever its causes might be-either inborn or acquired or a combination-these were not relevant for the legal and political assessment of homosexuality and individual responsibility. ${ }^{99}$

Although Moll exposed a weakness in Hirschfeld's emancipatory strategy, his own actions as an expert witness were no more consistent, as his involvement in the sensational Moltke-Eulenburg scandal (1907-9) makes clear. Moll and Hirschfeld presented conflicting testimonies in one of the trials following the allegation of the journalist Maximilian Harden that two of Kaiser Wilhelm's confidants, Count Kuno von Moltke and Prince Philipp zu Eulenburg, were homosexuals who secretly undermined Germany's national interest. Moltke then charged Harden with slander, creating a legal and media spectacle that represented the most sustained public discussion of homosexuality in Germany to date. Basing himself on the testimony of Moltke's disaffected ex-wife, Hirschfeld declared that her former husband showed many mental features that were typical of homosexual men, such as feminine affinities, sentimentality, artistic sense, and an inclination to mysticism. On the basis of this report, the court decided that Moltke's homosexual orientation was proven, and it discharged Harden.

This verdict was annihilated, however, and a new trial followed. After the testimony of Moltke's ex-wife was disqualified because she supposedly suffered from hysteria and Moltke and Eulenburg had declared under oath that their close friendship was pure, Moltke's attorneys called upon Moll as a new expert witness. Moll not only confirmed that Hirschfeld's testimony drew upon the unreliable statement of a hysterical woman; he also reproached him and other homosexual activists such as Adolf Brand for their eagerness to diagnose homosexuality in cases where it was dubious. In his report he discarded Hirschfeld's conclusions as biased and arbitrary: "One should not derive a person's homosexuality or even homosexual disposition from some artificially assembled fragments or particularly eye-catching psychic peculiarities." Hirschfeld had confused sentimental friendship, indulging in poetry and music, and effeminate behavior among men, which were part of the refined mores in aristocratic circles, with homosexuality. "What right

${ }^{99}$ Moll, "Probleme der Homosexualität," 174-79; Moll, Untersuchungen, 543-47, 555-56, 815; Moll, "Die widernatürliche Unzucht," 5-7; Moll, "Sexuelle Zwischenstufen" (1902), 427-28. See also Moll, "Die Behandlung der Homosexualität," 5; Moll, "Sexuelle Perversionen, Geisteskrankheit und Zurechnungsfähigkeit," 29-30, 66-68; Moll, "SexualPsychologie und -Pathologie," 74; Krafft-Ebing, Psychopathia sexualis, ed. Moll, 712, 77779; Moll, "Der 'reaktionäre' Kongress," 324. See also Matthew Conn, "Sexual Science and Sexual Forensics in 1920s Germany: Albert Moll as (S)Expert," Medical History 56, no. 2 (2012): 201-16, here 211-12. 
do we then have," Moll continued, "to draw conclusions about some sort of unconscious homosexuality rather than speak of friendship?"100 After Moll thus cleared Moltke of being homosexual, Harden was sentenced for libel, and Hirschfeld withdrew his earlier diagnosis, admitting that intimate friendship did not necessarily indicate a homosexual orientation. The press now vilified him, and public opinion turned against the homosexual movement. He must have felt betrayed after receiving no support from other authorities in the field of sexology such as Moll. Moll even added fuel to the flames by pointing to the self-destructive consequences of Hirschfeld's way of acting as well as Brand's reckless strategy of revealing the assumed homosexuality of high-ranking authorities in order to expose hypocrisy and double standards. This so-called path over corpses, against which Moll had warned before, had now caused a backlash against the homosexual movement, and homosexuals suffered the consequences. ${ }^{101}$

In his bitter account of the damaging consequences of the scandal for the homosexual movement, Hirschfeld accused Moll of dishonesty and of having fueled homophobic press coverage of Hirschfeld's role in the trial. According to Hirschfeld, Moll's testimony contradicted his earlier support for the repeal of Paragraph 175 and the arguments of Die Conträre Sexualempfindung, where he had acknowledged an overlap between samesex love and friendship and where he had argued that homosexuals could deceive themselves by confusing sexual love and friendship. ${ }^{102}$ Hirschfeld's comments indeed raise questions about Moll's incoherent arguments about the relation between, on the one hand, homosexuality and, on the other hand, intimate friendship and a more spiritual eroticism. ${ }^{103} \mathrm{~A}$ few years after the Moltke trial Moll published a historical study about "famous homosexuals" in which he stressed that close friendships between men in eighteenth-century literary circles were not necessarily homosexual relationships and that such intimate bonds should be understood in their particular

100 Albert Moll, "Einige Lehren des Harden-Prozesses," Zeitschrift für ärztliche Fortbildung 5 (1908): 60-63, see 61-62; cf. Norman Domeier, Der Eulenburg-Skandal: Eine politische Kulturgeschichte des Kaiserreichs (Frankfurt: Campus Verlag, 2010), 167-70, 200, 269; Beachy, Gay Berlin, 120-39.

${ }^{101}$ Moll, "Einige Lehren," 61; cf. Moll, "Sexuelle Zwischenstufen” (1902), 431-32; Moll, "Inwieweit ist die Agitation"; Hirschfeld, Von einst bis jetzt, 89; Charlotte Wolff, Magnus Hirschfeld: A Portrait of a Pioneer in Sexology (London: Quartet Books, 1986), 72-73, 80.

${ }^{102}$ Magnus Hirschfeld, Sexualpsychologie und Volkspsychologie: Eine epikritische Studie zum Harden-Prozess (Leipzig: Georg H. Wigands Verlag, 1908), 4, 10, 15, 23, 28.

${ }^{103}$ Bernd-Ulrich Hergemöller's claim that Moll belonged to Kuno von Moltke's circle of friends and that he was therefore asked and motivated to invalidate Hirschfeld's compromising expert testimony cannot be substantiated. See Bernd-Ulrich Hergemöller, "Albert Moll," in Mann für Mann: Biographisches Lexikon, ed. Bernd-Ulrich Hergemöller (Hamburg: Suhrkamp, 2001), 513-14. In his memoirs Moll does mention that he was acquainted with Countess Eliza von Moltke-Huitfeld, the wife of Helmuth Johannes Ludwig von Moltke, commander in chief of the German army (1906-14), who belonged to another branch of the family. Moll, Ein Leben, 100-101. 
cultural-historical context. ${ }^{104} \mathrm{~A}$ class prejudice is noticeable here: whereas Moll warned time and again against the danger of casual forms of homosexual behavior common within socially diverse milieus like the homosexual subculture and sex-segregated institutions, he argued that close friendships between men in the intellectual and artistic upper echelons of society were different from homosexual relations. At the same time, he complicated this issue by repeatedly suggesting that the cultivation of intimate friendship was exploited by homosexuals as a cover for same-sex desire and behavior. Sharply criticizing some pedagogues, in particular Eduard Spranger and Gustav Wyneken, who, according to Moll, misused the concept of eros in order to highlight the supposedly spiritual and pedagogical dimensions of same-sex (and particularly teacher-student) relationships, he insisted that eroticism was never nonphysical but was always part of what he had defined as the attraction drive - the relational component of the sex drive that could not be separated from its genital roots. "For many homosexuals," Moll smirked, "it is an extraordinary pleasure that eros is publicly presented as something that is distinct from sexuality," but this contradicted what he had seen in his medical practice. "I had the possibility to speak to several Edeluranier [noble-minded uranians-his label for Spranger, Wyneken, Brand, and their like] and to ask them: 'What about your erection and your ejaculation?' They cannot evade an answer to such questions, and then they admit: yes, these are there. So why speak about eros here instead of sexuality?" 105

Even more sarcastic were Moll's comments on the efforts of homosexual activists to educate the public through the creation of a feature film, Anders als die Andern (Different from the others), which was produced in close cooperation with Hirschfeld and in which he made a cameo appearance. The film was shown in several German cities in 1919 and 1920 in the hopes of garnering public support for the fight against Paragraph 175. Together with Kraepelin and the psychiatrist Siegfried Placzek, who shared Moll's negative opinion about Hirschfeld, Moll provided expert advice to the Berlin Censorship Chamber on the movie, judging it to be unsuitable for public viewing because it might seduce impressionable young men into homosexuality. ${ }^{106}$ "The people who should be educated should be informed not only about what they [homosexuals] feel," Moll dryly commented, "but also about what they do. One should tell the people: your own children, in particular pupils and students, are running the risk of being victimized

${ }^{104}$ Albert Moll, Berühmte Homosexuelle (Wiesbaden: J. F. Bergmann, 1910), 1-16. See also Moll, "Physiologisches und Psychologisches."

${ }^{105}$ Moll, "Homosexualität und sogenannter Eros," 143-44.

${ }^{106}$ Moll, Ein Leben, 148; Wolff, Magnus Hirschfeld, 194; James D. Steakley, "Cinema and Censorship in the Weimar Republic: The Case of Anders als die Andern," Film History 11, no. 2 (1999): 181-203, see 192; Marhoefer, Sex and the Weimar Republic, 35, 44; Clayton J. Whisnant, Queer Identities and Politics in Germany: A History 1880-1945 (New York: Harrington Park Press, 2016), 179-80. 
by homosexuals. . . A homosexual film shows how a homosexual musician instructs a young man, trains him as an artist. It does not picture, however, what they do during the breaks and the moments when they are together but don't play music. Mutual masturbation, coitus inter femora, the frequent insertion of the male member in the mouth-all of this is not shown in the movie nor by the campaigners for idealized homosexuality." 107

\section{Professional Rivalry}

Moll's continuing antagonism toward Hirschfeld was exacerbated by their competition for prominence in the field of sexology. When in 1913 Hirschfeld, Albert Eulenburg, and Iwan Bloch initiated the Society of Physicians for Sexual Science and Eugenics (Ärztliche Gesellschaft für Sexualwissenschaft und Eugenik), Moll reacted by cooperating with the sexologist Max Marcuse and the economist Julius Wolf to found the International Society for Sexual Research (Internationale Gesellschaft für Sexualforschung). Moll and his associates claimed that Hirschfeld's organization was motivated by leftist and populist politics and dominated by a one-sided biomedical approach, while their society was truly scientific and politically neutral and also provided scope for a broader, cultural perspective on sexuality. ${ }^{108}$ After Hirschfeld had organized the first international conference on sexuality in 1922 in Berlin, Moll planned another one, claiming that Hirschfeld's event was politically biased and therefore harmful for the scientific stature of sexology. In 1926 Moll enjoyed his finest hour as chairman of the International Conference on Sexological Research in Berlin. ${ }^{109}$ Neither Freud nor Hirschfeld attended. Freud received an invitation but declined it after Moll, according to Freud, had expressed his aversion of psychoanalysis at a press conference. ${ }^{110}$ Hirschfeld, who had not been invited at all, maintained, incorrectly according to Moll's account, that Moll had passed him over because of his leftist (social democratic) orientation, implying that Moll was conservative. Moll retorted with the

${ }^{107}$ Moll, Behandlung der Homosexualität, 65-66.

${ }^{108}$ About the shaping of German sexology as a scientific and professional field and the internal rivalries, see Andreas Pretzel, "Zur Geschichte der "Ärztlichen Gesellschaft für Sexualwissenschaft' (1913-1933)-Dokumentation und Forschungsbericht," Mitteilungen der Magnus-Hirschfeld-Gesellschaft 24/25 (1997): 35-122; Pretzel, "Sexualreform"; Andreas Seeck, "Das Verhältnis von Wissenschaft und Politik im Selbstverständnis der Sexualwissenschaft," in Ferdinand, Pretzel, and Seeck, Verqueere Wissenschaft?, 199-212; Seeck, "Aufklärung oder Rückfall? Das Projekt der Etablierung einer 'Sexualwissenschaft' und deren Konzeption als Teil der Biologie," in Seeck, Durch Wissenschaft zur Gerechtigkeit?, 173-205; Sigusch, Geschichte der Sexualwissenschaft, 124-64.

${ }^{109}$ Albert Moll, "Zum Kongress," Zeitschrift für Sexualwissenschaft 13 (1926): 193-95; Moll, "Der 'reaktionäre' Kongress," 321-22; Moll, Ein Leben, 228-34; Conn, "Sexual Science," 201-2, 214.

${ }^{110}$ Ernest Jones, The Life and Work of Sigmund Freud: Vol. 3 The Last Phase 1919-1939 (New York: Basic Books, 1957), 127. 
accusation that Hirschfeld had tried to sabotage his conference and that if he had come, then other prominent scientists would have declined the invitation. He accused Hirschfeld of a lack of scientific objectivity, and he also claimed to "have a lot of material" about Hirschfeld's "problematic nature" (a clear allusion to Hirschfeld's homosexuality), which he would reveal if he felt forced to do so. All of this was a severe blow to Hirschfeld's self-esteem and reputation. ${ }^{111}$

Eight years later, when Germany was under Nazi rule and Hirschfeld had returned to Europe from his world tour but was exiled in Paris, Moll continued the character assassination of his foe. In a 1934 letter to the dean of the Parisian medical faculty and copied to the German Ministry of Foreign Affairs, Moll cast doubt on Hirschfeld's expertise and again hinted at his homosexuality by countering Hirschfeld's assertion that it was his Jewish background and social democratic affiliations that prevented a return to Germany; the real reason of Hirschfeld's exile, Moll insisted, was "misconduct in a totally different direction." 112 Moll's memoirs, written two years later, expressed his contentment that the National Socialist government had executed a thorough "cleanup" of homosexual schemes that would have put so many youths at risk. ${ }^{113}$ Arising from the hope that the Nazis would defend law and order and fight sexual immorality, the last statement was probably part of an effort to placate the new regime, which in fact was as threatening to Moll, himself a Jewish sexologist, as it was to Hirschfeld.

Moll's ruthless attempt to slander Hirschfeld certainly revealed the worst of Moll's rancorous personality. This should, however, not detract from a serious consideration of his overall sexual theory, which was in many ways more original, nuanced, and farsighted than Hirschfeld's approach. A large part of Moll's criticism of Hirschfeld was not without relevance in the light of Hirschfeld's problematical sexological and emancipatory legacy, to which some historians have drawn attention. ${ }^{114}$ Hirschfeld's fight for acceptance of homosexuality and against legal discrimination was intrinsically linked to a deterministic biogenetic explanation of homosexuality that defined it as being innate, clearly delineated, fixed, and rooted in gender inversion. His biological

${ }^{111}$ Moll, "Der 'reaktionäre' Kongress," 321-25; Wolff, Magnus Hirschfeld, 243.

${ }^{112}$ Sigusch, "The Sexologist Albert Moll," 197-98, 200. See also Volkmar Sigusch, "Albert Moll und Magnus Hirschfeld: Über ein problematisches Verhältnis vor dem Hintergrund unveröffentlicher Briefe Molls aus dem Jahr 1934," Zeitschrift für Sexualforschung 8 (1995): 122-59.

${ }^{113}$ Moll, Ein Leben, 151.

114 The most useful and complete overviews are provided in Seeck, Durch Wissenschaft zur Gerechtigkeit?, in particular the introduction by Andreas Seeck (7-23) and the chapters by Volkmar Sigusch (57-61, 63-68, 125-27), Grau (85-89), Herzer (91-98, 106, 157-72), Herrn (111-24, 253-64), and Danecker (129-32); Herzer, Magnus Hirschfeld, 8, 76, 8081; Kirsten Leng, "Magnus Hirschfeld's Meanings: Analysing Biography and the Politics of Representation," German History 35, no. 1 (2017): 96-116. 
reductionism implied traces of pathological thinking and degeneration theory, and it was entangled with eugenic assumptions. He suggested that homosexuals should not propagate because of the considerable risk that their offspring would suffer from degenerative disorders. Arguing that the natural purpose of homosexuality was in fact the prevention of degeneration, Hirschfeld was willing to link the decriminalization of homosexual intercourse with a legal ban for homosexuals to have children. ${ }^{115}$ Hirschfeld also tended to applaud any theory or research in the fields of evolutionary theory, genetics, embryology, endocrinology, and brain anatomy that appeared to confirm his biological view, with little consideration of their possible application against homosexuals. Thus he embraced the endocrinological research by Eugen Steinach and did not fundamentally question the efforts of Steinach and others to cure homosexual men by transplanting "heterosexual" testicles in them. ${ }^{116}$

As we have seen, Moll fundamentally questioned biological reductionism and determinism as well as a clear delineation of hetero- and homosexuality. He showed skepticism about somatic explanations and treatments of homosexuality, although he favored psychological cures. Again and again he expressed severe doubts about the swelling tide of eugenics and "racial hygiene," which in his view were based on wishful thinking rather than solid scientific underpinnings. ${ }^{117}$ Knowledge about heredity and genetics as well

${ }^{115}$ Magnus Hirschfeld, "Sind sexuelle Zwischenstufen zur Ehe geeignet?," Jabrbuch für sexuelle Zwischenstufen 3 (1901): 37-71.

116 Magnus Hirschfeld, "Operative Behandlung der Homosexualität," Jahrbuch für sexuelle Zwischenstufen 17 (1917): 189-90; Hirschfeld, "Die Untersuchungen und Forschungen von Prof. E. Steinach über künstliche Vermännlichung, Verweiblichung und Hermaphrodisierung," Jahrbuch für sexuelle Zwischenstufen 17 (1917): 3-20; Hirschfeld, "Ist die Homosexualität körperlich oder seelisch bedingt? Eine Erwiderung [auf E. Kraepelin]," Muenchener medizinische Wochenschrift 65, no. 11 (1918): 298-99, see 299; Hirschfeld, Sexualpathologie, vol. 2, Sexuelle Zwischenstufen: Das männliche Weib und der weibliche Mann (Bonn: A. Marcus und E. Weber, 1918), 205, 218; Hirschfeld, Geschlechtskunde, vol. 1, Die körperseelischen Grundlagen (Stuttgart: Julius Püttmann, 1926), 573; Hirschfeld, Geschlechtskunde, vol. 3, Einblicke und Ausblicke (Stuttgart: Julius Püttmann, 1930), 15, 4243, 190; Hirschfeld, "Das Erbgericht: Betrachtungen zum deutschen Sterilisationsgesetz," Die Sammlung: Literarisches Monatsschrift 1 (1933): 309-19. See also Chandak Sengoopta, "Glandular Politics: Experimental Biology, Clinical Medicine, and Homosexual Emancipation in Fin-de-Siècle Central Europe," Isis 89, no. 3 (1998): 445-73.

117 Moll, Die Conträre Sexualempfindung, 222; Moll, Ärztliche Ethik, 404; Moll, "Perverse Sexualempfindung, psychische Impotenz und Ehe," 711-12, 717; Moll, "Über den Einfluss des grossstädtisches Lebens," 932-33; Moll, "Wann dürfen Homosexuelle heiraten?"; Moll, "Die Behandlung sexueller Perversionen," 12; Moll, "Sexuelle Hygiene," 907-19; Albert Moll, "Bevölkerungspolitik und Homosexualität," in Hundert Jahre A. Marcus und E. Webers Verlag, ed. A. Marcus und E. Webers Verlag (Bonn: A. Marcus and E. Webers Verlag, 1919), 313-16; Moll, Behandlung der Homosexualität, 15-16, 20-21; Krafft-Ebing, Psychopathia sexualis, ed. Moll, 694-99, 715; Moll, Polizei und Sitte, 107, 118-21; Moll, Ein Leben, 146-48. For an overview of Moll's attitudes toward eugenics in general and sterilization in particular, see Thomas Bryant, "Sexological Deliberation and Social Engineering: Albert Moll and the Sterilisation Debate in Late Imperial and Weimar Germany," Medical History 56, no. 2 (2012): 237-54. 
as assumptions about the danger of degeneration, Moll contended, were shaky and contentious. Apart from inborn physical traits, it was difficult to decide whether other personal and behavioral characteristics were inherited or acquired. Neither was there any proof for the central tenet of degeneration theory that tainted individuals inevitably passed their disorders on to their offspring, resulting in continuous deterioration in successive generations. Moll believed that the protagonists of eugenics were overstressing the unavoidability of regression while ignoring the possibility of natural regeneration. He further raised practical and ethical objections against eugenic interventions such as sterilization, vasectomy, castration, marriage guidance councils, institutionalization, and euthanasia. In the late 1920s he strongly criticized proposals for far-reaching coercive eugenic legislation in Germany. ${ }^{118}$ The only valid reason for sterilization or castration was a medical indication in individual cases on the basis of personal health interests and informed consent. Any other social, economic, hygienic, or racial purpose promulgated by third parties or the state could, in his view, not be justified. Thus he also opposed castration of sexual offenders as punishment, cure, or prevention of recidivism or degenerative offspring. As an alternative for eugenics and racial hygiene, Moll advocated social and mental hygiene, educational programs in the field of child-raising, and the broadening of a solid middle class through the promotion of social mobility and amelioration. Hirschfeld certainly did not rule out such social and psychological approaches, but his largely uncritical and enduring (until his death in 1935) belief in eugenics-although he distanced himself from its entanglement with racist thinking—sets him apart from Moll's more circumspect stance. ${ }^{119}$

\section{Older and Newer Models of Homosexuality}

Moll's professional and political rivalry with Hirschfeld was not the only motive for his ambivalent and partly regressive judgment of homosexuality. His intricate and contradictory understanding of it was also motivated by his awareness of diverse social realities of homosexuality, as well as sexology's effects on society. In his early works, in particular Die Conträre Sexualempfindung and Untersuchungen über die Libido sexualis, Moll's focus was on the idea of innate homosexuality as a personal characteristic of a clearly delineated minority. This idea was only partly in line with the

${ }^{118}$ Gustav Boeters and Albert Moll, "Sexualwissenschaftliche Rundschau: Die Verhütung unwerten Lebens," Zeitschrift für Sexualwissenschaft 12, no. 1 (1925): 30-33; Albert Moll, "Über die Indikation der praktischen Eugenik," in Marcuse, Verbandlungen des internationalen Kongresses für Sexualforschung, 4:146-55; Moll, "Sterilisierung und Verbrechen," Kriminalistische Monatshefte 3 (1929): 121-26.

${ }^{119}$ Volkmar Sigusch, "War Magnus Hirschfeld ein 'geistiger Vorläufer des Faschismus,"” in Seeck, Durch Wissenschaft zur Gerechtigkeit?, 125-27; Rainer Herrn, "'Phantom Rasse: Ein Hirngespinst als Weltgefahr'; Anmerkungen zu einem Aufsatz Magnus Hirschfelds," in Seeck, Durch Wissenschaft zur Gerechtigkeit?, 111-24. 
current explanation of homosexuality as a form of gender inversion. He suggested that not all homosexuals were inverts, that effeminacy and male homosexuality were not intrinsically related, and that homosexuality (as well as heterosexuality) should rather be understood in terms of sexual object choice. The dichotomy and equivalence of exclusive hetero- and homosexuality were central in these works, and this would imply, as some of his vocal middle- and upper-class clients and informants underlined, that homosexual relationships should be treated with the same respect for equality, privacy, and mutual consent accorded to heterosexual relationships. Moll's work was thus pioneering in its support for the creation of a sexual order that would allow for the coexistence of a heterosexual majority and a well-defined minority of homosexuals whose sexual and gender roles (active or passive) were not so relevant anymore because they were now supposedly embedded in equality and mutual consent instead of inequalities of age and class. As some of Moll's case histories testify, he was drawing on a self-consciously affirmative and possibly liberationist ideal of consensual same-sex desire that already existed in the late nineteenth century but that would not become the dominant pattern of social practice until well after the Second World War.

From the early 1900s on, Moll shifted his attention to more diffuse, fleeting, occasional, and acquired forms of same-sex desire and behavior, which did not exclude heterosexual desire and which were precipitated by situational and social influences, habits, or periods in life, in particular the sexually undifferentiated phase of puberty and adolescence. This perspective was related to his view of sexuality as a transgressive force characterized by indeterminacy, fluidity, contingency, and instability. To a large extent it mirrored older patterns of thinking rooted in Christian thinking about sodomy, as well as a more secular and bourgeois discourse since the late seventeenth century about decadent life-styles. These perspectives referred to same-sex behavior as part of a more general sinful, hedonistic, and depraved sensuality that manifested moral corruption, laxity, or overindulgence and that arose from age differentials, class inequalities, and environmental influences such as sex-segregated institutions. Moll transformed this moralistic discourse about sexual debauchery into a more timely and sophisticated sexological explanation of the genesis of specific sexual desires, either ephemeral or more durable, and explained them in terms of the interaction between constitutional factors, environmental influences, and life experiences. ${ }^{120}$

My impression is that Moll could not escape the feeling that the way he had pictured homosexuality in the 1890s-as an inborn disposition of a clearly delineated minority that was determined by either gender inversion or object choice-was at odds with certain social realities. The third

${ }^{120}$ Krafft-Ebing, Psychopathia sexualis, ed. Moll, 671; see also Chris Brickell, "Sexology, the Homo/Hetero Binary, and the Complexities of Male Sexual History," Sexualities 9, no. 4 (2006): 423-47. 
sex theory coming out of the work of Ulrichs and Hirschfeld's movement implied that urnings, who possessed effeminate mental characteristics in male bodies, were not looking for sexual contact with each other but with "real" masculine men. And it became clear to Moll that a substantial number of such men who did not identify themselves as homosexual because of their active role in intercourse were available for same-sex contacts, although in terms of object-choice they might prefer women and should be, according to Moll's dichotomy of hetero- and homosexuality, considered as heterosexuals. Hirschfeld's view, although highlighting a fixed and closed-off homosexual category, particularly in his more political writings, at the same time implied sexual border-crossing and an undermining of the hetero/homo dichotomy as far as concrete behavior was concerned. Drawing on his growing experience in medical practice, forensic psychiatry, and his knowledge of the homosexual subculture, Moll moved away from his earlier conceptualization of homosexuality. A far larger spectrum of same-sex behaviors, belying a strict differentiation of hetero- and homosexuality, appeared to be prevalent in the early twentieth century. Large urban centers such as Berlin offered plenty of opportunities for homosexual encounters; certain public meeting places had become well-known sites of congregation (cafés, restaurants, hotels, parks, swimming pools, bathhouses, public urinals, railway stations, promenades, and shopping malls), and male prostitutes, soldiers, sailors, and young working-class men were available for money and other favors. For the most part, such contacts involved inequalities and differences of class and age and of active versus passive sexual roles. ${ }^{121}$ What worried Moll in particular was the crossing of age differences and the mixture of homo- and heterosexual behavior. And his anxiety was intensified by the way the general public was influenced by popularized sexological knowledge.

\section{AnXiety about "Sexualism"}

Against the background of the Moltke-Eulenburg scandal, Moll reported the story of a father's embarrassment when asked by his little son what a "pederast" was, a question the man deflected by saying it was just another

${ }^{121}$ For descriptions, see Hugländer, "Aus dem homosexuellen Leben Alt-Berlins"; Magnus Hirschfeld, Berlins drittes Geschlecht, in Grossstadtdokumente, vol. 3, ed. Hans Ostwald (Berlin: H. Seemann, 1904); Hans Ostwald, Das Berliner Dirnentum: Männliche Prostitution, 2 vols. (Leipzig: Verlag Fiedler, 1906); Hirschfeld, Von einst bis jetzt, 38-46; Wolfgang Theis and Andreas Sternweiler, "Alltag im Kaiserreich und in der Weimarer Republik," in Eldorado: Homosexuelle Franen und Männer in Berlin 1850-1950, ed. M. Bollé (Berlin: Fröhlich und Kauffmann, 1984), 48-73; Beachy, "To Police and Protect"; and Beachy, Gay Berlin, 42-84, 187-219. The surroundings of the Kurfürstendamm, where Moll lived and worked, was one of the areas where male prostitutes offered their services (Beachy, Gay Berlin, 203). 
word for pedagogue. ${ }^{122}$ This anecdote sheds light on Moll's growing worry about the "sexualization" of modern consciousness and public life, which he felt would lead to a tendency to see diverse feelings and behaviors in a sexual light and to heightened concern about sexual orientation. An increasing number of men and women, he reported, had consulted him with groundless suspicions about their partner possibly being homosexual. ${ }^{123}$ Apparently, sexuality had become the subject of endless self-examination and the pivot of emotional problems such as fears of being abnormal, conflicts between fantasies and the realities of everyday life, and worries about sexual performance. Psychoanalysis in particular, Moll believed, had provoked a sexualized preoccupation with scrutinizing inner life that did more harm than good. "This manner of incessantly searching for the sexual, not only in adults but also in children, and thereby inciting even more sexual thoughts," Moll commented, "can only be regarded as dangerous for morality and health." ${ }^{124} \mathrm{He}$ clearly perceived the feedback effect not only of psychoanalysis but also of medical sexology, in particular of published case histories and autobiographical accounts in his own and other sexological works. Such life stories not only reflected but also tended to advance and shape — and in his view also deform —-individual self-reflection and sexual awareness.

All of this, Moll assumed, was to a large extent an effect of the increasing spread of sexual discourse and imagery in popular culture and public debate. The growing public visibility and commercialization of sexuality heightened sexual awareness and was, he wrote, "the reason why so many take every opportunity to nose around for the sexual and in particular for the perverse." ${ }^{25}$ Even his own work had become embroiled in sensational "sexualism," as he recounted in his memoirs. A prospectus that advertised the French translation of his book about homosexuality - sent to some five thousand French doctors, lawyers, theologians, and teachers-provoked a prominent French politician, supported by a moral purity organization, to press charges against the publisher for distributing pornography. The case focused on the question of whether Moll's detailed description of Berlin's homosexual nightlife violated French antiobscenity law. The publisher was acquitted because the work had not been advertised to the general public. The French edition, including an account of the charges and the trial in the foreword, appeared in 1893, and its sales were boosted by the public attention. ${ }^{126}$

${ }^{122}$ Moll, "Sexuelle Hygiene," 894.

${ }^{123}$ Moll, "Einige Lehren," 63.

${ }^{124}$ Moll, "Die Behandlung sexueller Perversionen," 8; see also Moll, Das Sexualleben, 13, 82-84, 154, 171-72; 210-11; Moll, "Sexuelle Hygiene," 885, 893-95; Moll, Polizei und Sitte, 129-31; Moll, Ein Leben, 53-54, 71.

${ }^{125}$ Moll, "Einige Lehren," 63.

${ }^{126}$ Moll, Ein Leben, 155-56; Albert Moll, Les perversions de l'instinct genital: Étude sur l'inversion sexuelle basée sur des documents officiels (Paris: G. Carré, 1893). 
Although he was in favor of rational information and education about sexual matters, it appears that Moll recoiled from all the public attention and debate on sexuality that had been fueled by the popularization of sexological knowledge - and of which he himself was one of the main pioneers. If such sexualization also affected individuals who lacked the self-control and self-responsibility to hold back their desires and impulses-in particular, young and lower-class people-it had to be countered through preventive sexual hygiene and education, as well as raising the legal age of consent from sixteen to eighteen. His position on Article 175 did not change, but from around the time of the Moltke-Eulenberg scandal (1907-9), Moll added a new argument: its repeal would take away the need for homosexual activism and propaganda and thus diminish its public visibility. ${ }^{127}$

\section{Conclusion}

Moll opposed the more leftist sexual policies of Hirschfeld and others, yet his position was largely in line with the reformist course that characterized sexual governance in the Weimar Republic and it also largely foreshadowed the post-World War II sociopolitical regulation of sexuality in many parts of the Western world. ${ }^{128}$ Both trends leaned toward drawing clear boundaries between acceptance of sexual behavior of consenting adults in private (or in clearly defined subcultural spaces) and sexual expression that would not be tolerated in the wider public sphere. Granting sexual liberties to discreet and responsible (meaning, in practice, middle-class) citizens, including "decent" homosexuals, coincided with the marginalization and intensified control of particular groups, such as female and male prostitutes, promiscuous individuals, extravagant transvestites, and moral offenders. Branded as irresponsible, asocial, and mentally inferior, these groups were subjected to police surveillance, social monitoring, and coercive medical and welfare interventions. Moll's worries particularly served to herald the increasing focus, from the 1930s, in medical, psychological, and juridical discussions as well as popular publications, on the presumed likelihood and dangers of age-disparity in same-sex intercourse. Explanations of the genesis of sexual orientation, in particular those informed by psychoanalytic theory, were in line with Moll's views in highlighting the psychological vulnerability of teenagers and adolescents. The widely felt need to protect youths from seduction and moral corruption entailed that sex between adults and minors was increasingly subject to sanction and that

${ }^{127}$ Moll, "Inwieweit ist die Agitation"; Moll, Das Sexualleben, 286; Moll, Behandlung der Homosexualität, 67-70; Moll, "Der 'reaktionäre' Kongress," 323-24; Ellis and Moll, "Die Funktionsstörungen," 656; Moll, Polizei und Sitte, 106-10, 129-31.

${ }^{128}$ See Marhoefer, Sex and the Weimar Republic. Marhoefer's argument about the 1920s is largely in line with Dagmar Herzog's analysis of general developments in the twentiethcentury Western world. Dagmar Herzog, Sexuality in Europe: A Twentieth-Century History (Cambridge: Cambridge University Press, 2011). 
homosexual rights would increasingly be framed in terms of consensual sexuality between adults. ${ }^{129}$

Moll's otherwise levelheaded and pragmatic views reflected these regulative tendencies, which were based on an enlightened and liberal trust in rationality and science as well as sexual egalitarianism and the separation of the public and private spheres. He believed that it was not penal law or moral and religious authority that could promote sexual health but rather medicine, psychology, education, social hygiene and reform, and responsible citizenship. As we have seen, in his view neither nature nor culture guaranteed the spontaneous unfolding of relational heterosexuality. Therefore, the "natural pleasure" of (hetero)sexuality had to be actively promoted, while homosexuality and other perversions had to be discouraged as much as possible, and while their existence was inevitable, they needed to be limited to exclusive minorities and enclosed social spaces. The same-sex behaviors that Moll regarded as troublesome were those that threatened the firm boundary between homosexuality and heterosexuality and that occurred in public places and in sex-segregated, all-male settings, such as military barracks, prisons, ships, boarding schools, and dormitories, and, above all, that involved adult male attraction toward minors. ${ }^{130}$ Acceptable homosexual practices were those taking place in privacy and based on intimacy, equality, and reciprocity. Moll's arguments made it possible to imagine future public acceptance of the idea that there was just as strong a link between sexuality and love for homosexuals as there was for heterosexuals, thus paving the way for the normalization of homosexuality as the equivalent of heterosexuality.

Basically, Moll had already articulated this modern sexual model in the 1890s, decades before it would become mainstream. Around 1900 he was ahead of his time, but from the 1920s on the ideal of relational sexuality was more and more widely adopted, whereas his earlier innovative views of (homo)sexuality now turned into more defensive and regressive attitudes, which triggered his image as a conservative thinker. As a loner without a movement or followers, Moll failed to establish a lasting legacy, despite the fact that his approach largely overlapped with that of the League of Human Rights (Bund für Menschenrecht), the largest branch of the homosexual rights movement in the 1920s. Under the leadership of Friedrich Radszuweit, this organization claimed that it represented the mass of respectable and productive homosexual citizens of all political colors and distanced itself from Hirschfeld's Scientific-Humanitarian Committee as well as from its rival, Adolf Brand's Community of Self-Owners (Gemeinschaft der Eigenen). The league rejected the association of homosexuality with

${ }^{129}$ Herzog, Sexuality in Europe, 54, 63, 73, 78-80, 117-25; Marhoefer, Sex and the Weimar Republic, 120-22, 127, 133, 203.

${ }^{130}$ Moll, Das Sexualleben, 234-35, 237-39, 260, 248, 251, 274, 279; Moll, "Die Behandlung der Homosexualität," 21; Moll, "Die sozialen Formen," 364; Moll, "Die Erotik," 560-62; Moll, "Sexuelle Hygiene," 890-95. 
gender inversion, strongly condemned homosexual relations between adults and minors, and denied the relevance of scientific explanations of homosexuality, such as the third sex theory, for legal reform. Apparently, Radszuweit and his associates tried to enlist Moll's support by attending his international conference and joining the International Society for Sexual Research. ${ }^{131}$ There is no trace, however, of any response by Moll to their overture.

Another reason for Moll's marginal presence in the historiography may be that he does not fit in a "usable" history. The tendency to embrace a particular version of the past in order to fulfill present-day needs means that some historical narratives are prioritized over others and that some parts of the past are shunned. In the wake of the sexual revolution and the emergence of the modern gay movement in the 1960s and 1970s, Hirschfeld's movement has been foregrounded as the trailblazer of sexual reform and homosexual emancipation. His heroic stature even benefited from his status as a well-known Jewish and homosexual target of the Nazis. All of this fits well with the democratic national identity and sexual liberalism of Germany today. But such a usable history also entails the discarding of a sexual pioneer such as Moll and his advanced thinking about sexuality. A selective and presentist view of history may be unavoidable and useful for shaping public (including gay and lesbian) memory, but historical scholarship should distance itself from it and also point out the more multifaceted, confusing, and possibly unpleasant realities of the past. The late nineteenth- and early twentieth-century history of sexology, sexual reform, and homosexual activism, which was multilayered and conflict ridden, does not mirror current liberal or more leftist and politically correct notions of sexual emancipation.

Moll did not affirm or celebrate an outright emancipatory or liberationist approach of sexuality, but this does not mean that his way of thinking was a conservative underpinning of the moral status quo, as suggested by several historians. ${ }^{132}$ The cognitive dimension of his work, including ambiguities and contradictions, was in several ways more sophisticated and innovative, more "modern" than that of other influential authorities such as Hirschfeld. Already in the 1890s Moll had arrived at some basic insights about sexuality that Freud and his followers would claim as unique achievements of psychoanalysis from the early 1900s on. Moll's basic idea was that sexual desire is neither natural, definite, and inevitable nor made-up, accidental, and shaped by conscious will. His approach anticipated not only the Freudian perspective but also recent attempts to reconcile essentialist and

${ }^{131}$ Glenn Ramsey, "The Rites of Artgenossen: Contesting Homosexual Political Culture in Weimar Germany," Journal of the History of Sexuality 17, no. 1 (2008): 85-109; Andreas Sternweiler, "Die Freundschaftsbünde-eine Massenbewegung," in Goodbye to Berlin? 100 Jahre Schwulenbewegung, ed. Schwules Museum and Berlin Akademie der Künste (Berlin: Verlag Rosa Winkel, Schwules Museum, and Akademie der Künste, 1997), 95-104, see 102.

${ }^{132}$ See the works mentioned in footnote 1 , which present the dubious judgment that Moll was a conservative. 
constructivist positions through a foregrounding of the interplay between biological and psychological factors and the shaping force of social and cultural influences. ${ }^{133}$

The equation of sexual modernity with either liberation and emancipation or disciplinary control without considering the ins and outs of the underlying patterns of thought overlooks the ambiguities and dilemmas in the development of the science and politics of sexuality since the late nineteenth century. ${ }^{134}$ The core of sexual modernity is a fundamental perceptive transformation, a new mode of reasoning, that changed the definition and explanation of sexuality and the understanding of its meaning in human life. Sexuality was conceptualized as an inevitable and powerful natural force in human life with which everybody has to come to terms. The procreative norm was more and more replaced by emotional fulfillment as well as the relational aspect of sexuality, which advanced a focus on its experiential, psychological dimension, its interconnection with personal identity, and an increasing acknowledgment of sexual diversity. Moll not only articulated these features but also indicated that the modern experience of sexuality was multifarious and in several ways problematic.

\section{About the Author}

Harry Oosterhuis teaches history at the Faculty of Arts and Social Sciences of Maastricht University and is affiliated with the Huizinga Research School for Cultural History in Amsterdam. His research focuses on the cultural and social history of psychiatry and mental health care, of sexuality and gender, of health and citizenship, and of bicycling and cycling policies. His (partly coauthored and coedited) books include Homosexuality and Male Bonding in Pre-Nazi Germany: The Youth Movement, the Gay Movement

${ }^{133}$ See, for example, Liahne E. Gordon and Tony J. Silva, "Inhabiting the Sexual Landscape: Toward an Interpretive Theory of the Development of Sexual Orientation and Identity," Journal of Homosexuality 62, no. 4 (2015): 495-530.

${ }^{134}$ For different perspectives on sexual modernity, see Paul Robinson, The Modernization of Sex: Havelock Ellis, Alfred Kinsey, William Masters and Virginia Johnson (New York: Harper and Row, 1976); Michel Foucault, Histoire de la sexualité, vol. 1, La volonté de savoir (Paris: Gallimard, 1976); Davidson, The Emergence of Sexuality; Lawrence Birken, Consuming Desire: Sexual Science and the Emergence of a Culture of Abundance, 1871-1914 (Ithaca, NY: Cornell University Press, 1988); Howard H. Chiang, "Historicizing the Emergence of Sexual Freedom: The Medical Knowledge of Psychiatry and the Scientific Power of Sexology, 1880-1920," Journal of the North Carolina Association of Historians 16 (2008): 35-76; Chiang, "Liberating Sex, Knowing Desire: Scientia sexualis and Epistemic Turning Points in the History of Sexuality," History of the Human Sciences 23, no. 5 (2010): 42-69; Harry Oosterhuis, "Sexual Modernity in the Works of Richard von Krafft-Ebing and Albert Moll," Medical History 56, no. 2 (2012): 133-55; Leck, Vita sexualis; and Harry Oosterhuis and Ralph Matthew Leck, "Politics and the Study of Sexual Science? An Exchange between Harry Oosterhuis and Ralph Leck," H-Net Reviews in the Humanities \& Social Sciences, accessed November 14, 2018, https://www.h-net.org/reviews/showpdf.php?id=51478. 
and Male Bonding before Hitler's Rise (Haworth Press / Harrington Park Press, 2013); Stepchildren of Nature: Krafft-Ebing, Psychiatry, and the Making of Sexual Identity (University of Chicago Press, 2000); Verward van geest en ander ongerief: Psychiatrie en geestelijke gezondheidszorg in Nederland (1870-2005) (Nederlands Tijdschrift voor Geneeskunde / Bohn Stafleu Van Loghum, 2008); Psychiatric Cultures Compared: Psychiatry and Mental Health Care in the Twentieth Century; Comparisons and Approaches (Amsterdam University Press, 2005); "Historical Perspectives on Forensic Psychiatry," International Journal of Law and Psychiatry 37, no. I (2014); and Health and Citizenship: Political Cultures of Health in Modern Europe (Pickering \& Chatto, 2014; Routledge, 2016). 